\title{
Hedef Maliyetleme, Değer Analizi, Kaizen Maliyetleme ve Kısıtlar Teorisinin Entegrasyonu ile Lojistik Maliyetlerde Etkinliğin Sağlanması ${ }^{{ }^{*}}$
}

\author{
Ata KAHVECi \\ Dr. Öğr. Üyesi, Tarsus Üniversitesi, \\ Meslek Yüksekokulu, Dış Ticaret Programı \\ atakahveci@tarsus.edu.tr \\ Orcid ID: https://orcid.org/0000-0002-2010-614X \\ Ercüment OKUTMUŞ \\ Doç. Dr., Alanya Alaaddin Keykubat Üniversitesi, \\ İktisadi İdari Bilimler Fakültesi, İşletme Bölümü \\ ercument.okutmus@alanya.edu.tr \\ Orcid ID: https://orcid.org/0000-0001-8630-7561
}

\begin{abstract}
$\ddot{\mathbf{O z}}$
Küreselleşme ve bilgi teknolojilerindeki dönüşüm sonucunda tüm sektörlerde olduğu gibi lojistik sektöründe de lojistik faaliyetlerin doğru şekilde, doğru miktarda, doğru zamanda ve en uygun maliyet ile yerine getirilmesi beklenmektedir. Son derece kapsamlı ve detaylı olan lojistik faaliyetlerin yerine getirilmesi sürecinde işletmeler aynı zamanda çok ciddi bir lojistik maliyete de katlanmaktadırlar. $\mathrm{Bu}$ lojistik faaliyetlerin etkin bir şekilde yürütülmesi ve işletmeye maliyetinin doğru bir şekilde hesaplanması, maliyet düşürmenin etkin bir şekilde sağlanması işletmeler için büyük önem arz etmektedir. Bu noktada lojistik maliyetlerin hesaplanması ve optimize edilmesinde çağdaş maliyet yöntemleri birlikte kullanılabilmektedir. Türkçe literatürde lojistik maliyetler konusunda dört farklı çağdaş maliyet yönteminin entegre olarak kullanıldığı bir çalışma bulunmamaktadır. Yapılan çalışma ile çağdaş maliyet yöntemlerinden hedef maliyetleme, değer analizi, kaizen maliyetleme ve kisitlar teorisinin entegrasyonu sonucunda lojistik maliyetlerin nasıl azaltılacağı vaka analizi

\footnotetext{
${ }^{1}$ Makale Geliş/Kabul Tarihi: 01.02.2021/26.06.2021

* Bu çalışma "Çağdaş Maliyet Yöntemlerinin Entegrasyonu ile Lojistik Maliyetlerde Etkinliğin Sağlanması: Bir İhracat Firmasında Uygulama" isimli tez çalışmasından türetilmiştir.

Künye Bilgisi: Kahveci, A. ve Okutmuş, E. (2021). Hedef maliyetleme, değer analizi, kaizen maliyetleme ve kısitlar teorisinin entegrasyonu ile lojistik maliyetlerde etkinliğin sağlanmasi. Kahramanmaraşs Sütçü İmam Üniversitesi Sosyal Bilimler Dergisi, 18(2), 1247-1279. DOI: 10.33437/ksusbd.872497
} 
yöntemiyle ortaya konulmuştur. Bu araştırma kapsamında ortaya konan model ile öncelikle hedef maliyetleme ile işletmenin lojistik maliyetlerde maliyet indiriminin toplam tutarı 160.555,13 TL olarak hesaplanmış, değer analizi kapsamında yapılmış olan anket ile faaliyetlerin önem dereceleri belirlenmiştir. Daha sonra kaizen maliyetleme ile hangi lojistik alt faaliyette ne kadar maliyet indirilmesi gerektiği tespit edilmiş ve kısıtlar teorisi kullanılarak işletmenin ambalajlama faaliyetinde sahip olduğu kapasite kısıtı belirlenip ortadan kaldırılarak lojistik maliyetlerin etkinliği sağlanmıştır.

Anahtar Kelimeler: Lojistik, Lojistik Maliyetler, Çağdaş Maliyet Yöntemleri.

\title{
Enhancing the Efficiency of Logistics Costs by Integrating Target Costing, Value Analysis, Kaizen Costing and Theory of Constraints
}

\begin{abstract}
Globalization and progress in information technologies forces logistics sector to carry out logistics activities by performing optimally in terms of time, line, amount and cost. Companies bear significant logistics costs during the process of carrying out extensive and detailed logistics activities. Therefore, the accurate evaluation of logistics costs is very important for companies to ensure cost minimization. At that point, integration of contemporary costing methods can be a useful tool while evaluating and optimizing logistics costs. Research related to logistics costs literature in Turkish, in which four different contemporary costing methods are used integrally, do not exist. The purpose of the research is to reveal how integration of target costing, value analysis, kaizen costing and theory of constraints decreases logistics cost by using case study method. After the application of research model and evaluation of survey, 160.555,13 TL possible logistics cost decrease has been calculated primarily by using target costing. Secondary, the importance level of each logistics activity has been determined. Afterwards, possible decrease in cost of sub-logistic activities has been determined by applying kaizen-costing method. Then, constraints of company's packaging activity has been determined and eliminated by using theory of constraints. Hence, efficiency of logistics costs has been provided.
\end{abstract}

Keywords: Logistics, Logistics Costs, Contemporary Cost Methods.

\section{GíRIŞ}

İnsanlık tarihinin başlangıcından günümüze kadar olan süreçte, bir yerden başka bir yere ulaşım ve malların taşınması gibi konular daima çok büyük önem 
arz etmiştir. Geçmişte lojistik faaliyetler sadece belirli noktalar arasında yapılmakta ancak çok uzun sürmekteydi. Bugün ise internet ve bilgi teknolojilerindeki gelişmeler sonucunda Türkiye'de bulunan bir müşteri, ihtiyacı olan herhangi bir ürünü Çin, Amerika ya da üretilen herhangi bir noktadan online olarak sipariş vermekte ve siparişi kendisine teslim edilene kadar ürününün nerede olduğunu her aşamada takip edebilmektedir. Müşteriler açısından sadece siparişin verilmesi, merak edildiğinde ürünün nerede olduğunun öğrenilmesi ve teslimi gibi basit bir işlem olarak görülen lojistik, arka planda çok daha detaylı karmaşık ve yoğun faaliyetler bütününden oluşmaktadır. Lojistik; siparişlerin işlenmesi, taşıma, depolama, stok yönetimi, elleçleme, ambalajlama, paketleme, sigortalama, müş̧eri hizmetleri ve eğer faaliyet, ülkeler arasında gerçekleştiriliyor ise gümrükleme ve antrepo gibi ana başlıklar altında birçok alt faaliyetin gerçekleştirilmesini gerektirmektedir. Örneğin sadece taşıma başlı̆g 1 altında düşünülecek olursa taşınacak ürünün öncelikle demiryolu, karayolu, havayolu ya da denizyolu ile mi taşınacağı belirlenmeli ve sonrasında ise hangi aracın taşıma için en uygun olduğu, konteyner türleri, rota belirleme, şoför/kaptan/pilot ve bunlara yardımcı personelin belirlenmesi gibi birçok operasyonun gerçekleştirilmesi gerekmektedir. Görüldüğü üzere son derece kapsamlı ve detaylı olan lojistik faaliyetlerin yerine getirilmesi sürecinde işletmeler aynı zamanda ortaya çıkan çok ciddi maliyetlere de katlanmaktadırlar.

Türkiye'de işletme düzeyinde lojistik maliyetler, çalışlan sektöre göre değişmekle birlikte cironun \%5-15'lik kısmına karşıllik gelmektedir (Hacırüstemoğlu ve Şakrak, 2002: 111). İşletmeler için lojistik, sadece bir maliyet kalemi olmasının ötesinde zamanında yerine getirilmemesi durumunda üretimde, kalitede aksama ve sorunlara ya da müşteri memnuniyetinde ciddi bir azalmaya sebep olabilecek bir konudur. İşletmeler açısından stratejik açıdan önemi yüksek ve aynı zamanda büyük bir maliyet kalemi olan lojistik maliyetlerin belirlenmesi ve daha iyi yönetilebilmesi, lojistiğin hayatımızın bir parçası olduğu günümüzde büyük önem taşımaktadır. Ancak, literatür incelendiğinde; lojistik maliyetlerin azaltılması, kontrolü ve yönetilmesinde genellikle faaliyet tabanlı maliyetleme yönteminin kullanıldığı ve bulunan sonuçların geleneksel maliyet yöntemi ile karşılaş̧ırıldığı görülmektedir. Bunların dışındaki çalışmalar ise daha çok optimizasyon ve mühendislik boyutu ile ele alınmıştır. Yapılan literatür incelemesinde çağdaş maliyet yöntemlerinin entegre bir şekilde kullanılarak lojistik maliyetlerin azaltılmasına yönelik ikiden fazla yöntemin kullanıldığı bir araştırmaya rastlanmamıştır. Dolayısıyla bu araştırmanın amacı; 4 farklı (hedef maliyet, değer analizi, kaizen maliyetleme, kısıtlar teorisi) çağdaş maliyet yönteminin birbirine entegre edilerek kullanılması sonucunda işletmelerdeki lojistik maliyetlerin nasıl azaltılacağını bir örnek uygulama ile ortaya koymaktır. 


\section{LOJISTIK MALIYET KAVRAMI VE İNCELENMESİ}

Lojistik alanında önemli çalışmaları olan Christopher (2011: 2) lojistiği işletmenin envanterinde bulunan materyallerin, yarı mamullerin ve ürünlerin (ve bunlara ilişkin bilgilerin) organizasyon ve dağıtım kanalında akışı sağlanırken, aynı zamanda bugün ve gelecekteki karlılığın maksimize edilebilmesi için minimum maliyetle siparişlerin tesliminin stratejik olarak yönetilmesi süreci olarak tanımlamaktadır. Bu süreç içinde yerine getirilmesi gereken lojistik faaliyetler ise Engblom ve arkadaşları (2012: 29) tarafından; ulaşım, depolama, envanterlerin taşınmas1, lojistik yönetim, paketleme ve endirekt lojistik maliyetler olarak gruplanmıştır. Taşkın ve Durmaz (2012: 41) ise yaptı̆̆ çalışmada lojistik faaliyetleri; ulaştırma, envanter yönetimi müşteri hizmetleri, sipariş işleme ve talep tahmini gibi ana faaliyetler ve üretim planlaması, ambalajlama, tesis (yer seçimi), depolama, satın alma, diğer faaliyetler gibi destekleyici faaliyetler başlıkları altında incelemiştir.

Lojistik maliyetin farklı ve kapsamı değişen birçok tanımı olmakla birlikte en geniş kapsamda, işletmelerin gerçekleştirdiği lojistik faaliyetler sonucunda ortaya çıkan, diğer bir deyişle işletmelerin lojistik faaliyetler için katlandıkları fedakarlıkların parasal tutarı olarak tanımlanabilir (Tokay vd., 2011: 227). Weiyi ve Luming (2009: 538) ise lojistik maliyetlerin tedarik, taşıma, dağıtım/teslimat, sipariş, iletişim, ambalajlama, depolama ve elleçleme gibi belirgin olan maliyetler; ve stok bulundurma (hasar, firsat ve faiz maliyeti) ile diğer lojistik hizmet maliyetleri (koordinasyon ve düşük kalitedeki insan kaynağı maliyeti) gibi belirgin olmayan maliyetlerin toplamından oluştuğunu ifade etmiştir. Görüldüğü üzere, lojistik maliyetlere ilişkin tanımlar detayları açısından birbirinden farklı olsa da özleri itibarı ile lojistik faaliyetler sonucunda katlanılacak maliyetleri ifade etmektedirler. Bu maliyetlerin ölçülebilmesi ve yönetilmesi ise işletmelerin sadece pazarda var olmalarını değil aynı zamanda rakipleri karşısında rekabet üstünlüğü elde etmelerini de sağlamaktadır.

Lojistik maliyet bilgisinin işletmeler açısından tıpkı makineler, işgücü ve enerji kadar önem taşıdığını ve doğru kullanılması ile işletmedeki zayıflıkların giderilebileceğini söylemek mümkündür (Yurtay vd., 2014: 245). Elde edilen maliyet bilgilerinin yeterli seviyede olmaması durumunda, lojistik faaliyetler gerçekleştirilirken bir maliyet kaleminin diğer maliyet kalemleri ile ilişkisinin anlaşılması ve bunların kâr üzerindeki etkilerinin analiz edilmesi zorlaşmaktadır (Hacırüstemoğlu ve Şakrak, 2002: 112). Buna ilave olarak her bir lojistik faaliyetin üretilen ürün ya da hizmete daha fazla bir değer ekleyip ekleyemediğinin ölçülmesi maliyet bilgisi eksikliği sebebiyle mümkün olmamaktadır (Sevim ve Elmac1, 2007: 103). Amerika'da yapılan bir araştırmada "lojistik maliyetlerde sağlanacak \%5'lik bir tasarrufun kârlıllk üzerindeki etkisinin, satışların \% 20 artırılmasının kârlılık üzerinde sağlayacağı etkiye eşit 
veya daha fazla olabileceği" (Robeson ve Copacino, 2000: 271'den aktaran Tokay vd., 2011: 234) tespiti dikkate alınacak olur ise, lojistik maliyete ilişkin bilgilerin elde edilmesinin ve doğru yönetilmesinin işletme performansı üzerindeki olumlu etkisinin önemi daha net anlaşlabilecektir.

İşletmeler için çok önemli olan lojistik maliyet bilgisinin elde edilebilmesi için; sipariş girişinden tamamlanmasına kadar olan tüm faaliyetleri kapsayan süreçte değer analizinin yapılması, sunulacak hizmetin maliyetinin gerçekleştirilen faaliyetler bazında tespiti ve son olarak tüm lojistik faaliyetlerin maliyetlerinin yönetilmesi konularına sistematik olarak yaklaşılması gerekmektedir (Quillian, 1991: 10). Fakat lojistik maliyetlerin hesaplanmas1 konusu hem hizmetlerin karmaşıklı̆g 1 ve takip zorluğu, hem de lojistik faaliyetleri izleyip kayıt altına alan bir maliyet sisteminin olmaması gibi nedenlerle oldukça karmaşık ve güçtür (Aslan ve Karavaizoğlu, 2009: 67; Sevim ve Elmacı, 2007: 103). Ayrıca, lojistik maliyetlerin hesaplanması ve ölçülmesinde işletmeler ve ülkeler bazında farklı yöntemler kullanılması da ortak ve net bir lojistik maliyet belirlenmesi konusunda zorluklar çıkarmaktadır. Örneğin, işletmeler lojistik maliyetlere ilişkin verileri toplarken öncelikle maliyet muhasebesi, süreç geliştirme, vergi gibi kendi muhasebe sistemlerinin ihtiyaçları doğrultusunda veri üretmektedirler. $\mathrm{Bu}$ nedenle, işletme seviyesinde toplanan veriler ulusal düzeyde lojistik maliyetlerin hesaplanmasında yetersiz kalmaktadır. Ulusal düzeyde bir lojistik maliyet hesaplaması için satışların veya hâsılanın yüzdesi, GSYİH'nın yüzdesi ve gerçekleşme tutarı olmak üzere üç şekilde olurken, yine bunların ortaya çıkabilmesi için istatistik temelli, anket ve vaka çalışması gibi ölçüm yöntemlerinden biri kullanılmaktadır (Rantasila ve Ojala, 2012: 9-10; Engblom vd., 2012: 29-30).

Lojistik maliyetlerin yönetilmesi ve hesaplanması konusunda kullanılan yöntemler literatürdeki çalışmalarda muhasebe dışı yöntemler ve muhasebe içi yöntemler olmak üzere ikiye ayrılmaktadır.

- Diğer sektörlerde olduğu gibi lojistik sektöründe de yöneticiler lojistik maliyetlerini hesaplamak ve kontrol edebilmek için farklı disiplinlerden yararlanarak sayısal olmayan yöntemler de kullanabilmektedir. Muhasebe dış1 yöntemlerden en çok kullanılanları; satışlar üzerinden tahmin yöntemi, analitik yöntem, yeni taşıma işletmeleri ile görüşme ya da mevcut taşıyıcı ile taşıma fiyatlarının tekrar görüşülmesi, taşıma maliyetlerinin azaltılmasına çalışılması, gelen ve giden lojistik süreçlerin izlenmesi, tedarikçilerle işbirliğinin artırılması, lojistikte yeni teknolojilerin kullanılması olarak sıralanabilir (Donath vd., 2002: 110; Özdemir, 2007: 64).

- Lojistik maliyetlere ilişkin faaliyetlerin çok detaylı ve karmaşık olması nedeniyle hesaplanması ve kontrolü de zordur. $\mathrm{Bu}$ nedenle maliyet hesaplamalarının sistematik ve detaylı olarak yapılması gerekmektedir. 
Muhasebe içi yöntemlerin uygulanmasındaki amaç; muhasebe biliminde kullanılan yöntemlerden faydalanıp, ilgili işletmenin muhasebe bilgi sistemindeki verileri işlemek, dönüştürmek ya da eksik olanları tamamlayarak lojistik maliyetlerin hesaplanması, yönetilmesi ve azaltılmasıdır. Çok detaylı ve birçok alt başlığı bulunan muhasebe içi yöntemler; geleneksel maliyetleme yöntemi ve çağdaş maliyet yöntemleri olarak ikiye ayrılmaktadır.

Bilgi teknolojileri ile otomasyonda yaşanan gelişmeler ve değişim sonucu işletmelerin ihtiyaç duydukları bilgilerin üretilmesi noktasında geleneksel yöntemler yetersiz kalmaktadır (Gürdal, 2007: 11). Bu yetersizlikleri gidermek üzere maliyetlerin hesaplanma sistemlerinin yeniden tasarlanması sonucunda ortaya çıkan yöntemler olarak adlandırılan çağdaş maliyet yöntemlerinden sadece hedef maliyetleme, değer analizi, kaizen maliyetleme ve kısitlar teorisi bu araştırma kapmasında kullanıldığından kısaca açıklanacaktır.

\section{HEDEF MALIYETLEME, DEĞER ANALİŻ, KAIZZEN MALIYETLEME ve KISITLAR TEORISIININ ENTEGRASYONU}

Literatürde farklı tanımları bulunan hedef maliyetleme; belirli fonksiyonellik ve kalite standardında olan ürünlerin üretilerek tahmin edilen (hedeflenen) satış fiyatında, arzu edilen kârlılık oranında satış yapabilmek için ürünün tüm yaşam dönemi süresince maliyetlerini dikkate alan yapılandırılmış bir yaklaşımdır (Cooper ve Slagmulder, 1997: 72). Burada önemli olan husus ürün ve hizmet fiyatını piyasanın belirlemesinin yanında ürüne ilişkin maliyetlerin \%80-85'inin geliştirme ve tasarım aşamasında oluşması nedeniyle işletmelerin maliyetlerini daha geliştirme ve tasarım aşamasında iken hesaplanması, kontrolü ve düşürülmesidir (Ergül, 2014: 42). Hedef maliyetleme yönteminin uygulama süreci müşteri ve işletme açısında değer yaratan ürünlerin üretilmesine odaklanan, işletmenin tüm bölümleri ve hatta tedarikçilerle iyi ilişkiler ve etkileşim sağlayan dinamik bir süreçtir (Ellram, 2006: 13). Uygulama sürecinde hedef satış fiyatı, hedef kâr marjı ve hedef maliyet belirlendikten sonra ürünlerin bileşenlerine (parça ve fonksiyonlara) indirgendiği hedef maliyetin ayrımlanması aşamasına gelinir (Bozdemir, 2010: 95). Bu aşama; ürün/hizmetin fonksiyonlarının belirlenmesi, her bir fonksiyonun görece öneminin belirlenmesi, ürün/hizmeti oluşturacak parçaların belirlenmesi, parçaların maliyetlerinin belirlenmesi, ürün/hizmeti oluşturan parçaların görece öneminin belirlenmesi, her bir parçanın hedef maliyet endeksinin oluşturulması, hedef maliyet endeksinin optimizasyonu ve diğer maliyet düşürme yöntemleri olmak üzere sekiz alt aşamadan oluşmaktadır (Bilginoğlu, 1995: 14; Ergül, 2014: 71-75).

Ürünlere ya da süreçlere kolaylıkla uygulanabilen değer analizi ile işletmelerde maliyet düşürmede son derece etkili sonuçlara ulaşılabilmektedir. $\mathrm{Bu}$ sonuçlara ulaşmak için sırasıyla; fonksiyonun tanımlanması, fonksiyonun 
değerlendirilmesi ve alternatiflerin geliştirilmesi adımlarında ölçüm ve analizler yapılır (Marzouk, 2011: 596). Örneğin ürünün parçaları ve özellikleri veya süreçler üzerinde fikir yürütmek için Değer Endeksi'nden faydalanılır. Bu endeks kısaca müşterilerin verdiği değer ile üreticinin verdiği değerin oranlanması ile bulunur. Bulunan değer 1'den büyükse işletme bu parça için daha fazla maliyete katlanmalıyken, bu rakam 1'den küçükse ilgili parçada müşteri öneminden daha fazla maliyete katlanıyor demektir (Örnek: 2003: 220). Bu noktada müşteri kavramının pazarlama alanında iç müşteri ve dış müşteri olmak üzere 2'ye ayrıldığı vurgulanmalıdır (Doğan ve Kılıç, 2008: 62-63). İç müşteri kavramı ile işletmenin herhangi bir basamağında çalışanlar ifade edilirken, dış müşteri kavramı ile işletme çalışanı olmayan müşteriler ifade edilmektedir (Pekmezci vd. 2008: 145; Doğan ve Kılıç, 2008: 62-63). Bu noktadan hareketle, bir ürün ile ilgili değer analizi söz konusu ise dış müşterilerin; işletme içindeki bir süreç ya da faaliyet ile ilgili bir değer analizi yapılacak ise de iç müşterilerin görüşlerinin alınmasıyla analizlerde kullanılacak verilerin daha doğru seçilebileceği söylenebilir.

Kaizen'in özü, kısa ve açık bir şekilde "iyileştirme" kelimesi ile ifade edilebilir. İşletme yöneticileri ve çalışanlarının tamamının dâhil olduğu, iş yaşamı, sosyal yaşam ve ev yaşamını da içine alan ve tüm alanlarda sürekli iyileştirmeyi amaçlayan bir felsefedir (Imai, 1986: 3). Kaizen maliyetleme ise maliyet etkinliğinin sağlanabilmesi ve işletme yönetimi tarafından belirlenmiş olan hedef maliyete ulaşılması için üretim süreçlerinin sürekli olarak iyileştirilmesini amaçlayan küçük fakat sık aralıklarda sürekli gelişmenin söz konusu olduğu ve üretimin her aşamasında maliyet indirimlerinin sürekli izlendiği bir yöntemdir (Ergül, 2014: 21). Kaizen felsefesi ya sürecin tamamına ya da spesifik bir ürüne uygulanarak kaizen maliyetlemenin içinde yer alır (Altınbay, 2006: 105). Kaizen maliyetlemenin başarılı bir şekilde uygulanabilmesi için iki şartın yerine getirilmesi gerekmektedir. Bunlardan ilki maliyet indirim hedefleri belirlendikten sonra oluşturulan kaizen çalışma grubunun hedeflerin gerçekleştirilmesinden sorumlu tutulmasıdır. İkinci kritik faktör ise kaizen süreci tekrar ve süreklilik üzerine kurulu olduğundan, bunun organizasyon kültürünün bir parçası haline getirilmesidir (Modarress vd. 2005: 1753). Aksi takdirde yapılacak olan uygulamaların süreçler üzerindeki etkileri kısıtlı olacak veya kaizen maliyetleme ile ulaşılması mümkün olan maliyet düşürme ya da süreç iyileştirme hedeflerine ulaşılamayacaktır. Muhasebe açısından kaizen maliyetleme yönteminin uygulama sürecinde hesaplanması gerekenleri Yükçü (2011: 941) sırasıyla; kişi başı son fiili maliyet, cari dönemdeki toplam tahmini maliyet, cari dönem toplam maliyet hedefi, cari dönem toplam kaizen maliyet hedefi, tahsis oran1, bir bölümün toplam kaizen maliyet hedefi olarak sıralamıştır. Bu hesaplamaların nasıl yapılacağına dair formüller uygulama kısmında detaylı olarak verilmiştir. 
1980'lerde Goldratt tarafından geliştirilen kısıtlar teorisi, kısıtların yönetilerek üretim süreçlerinde sürekli gelişmeyi amaçlayan bir yönetim felsefesi olarak tanımlanmaktadır (Geri ve Ahituv, 2008: 343; Ünal vd., 2006: 330; Tiryakigil, 2011: 62; Ronen, 2005: 1-2). Sistem geliştirme üzerine odaklanan kısıtlar teorisinde, sistem, birbirine bağlı çalışan süreçler ve/veya zincir olarak tanımlanmakta; kısıt ise zincirin en zayıf halkasını oluşturmaktadır (Nave, 2002: 75). Kısıtlar temel olarak makine kapasitesi gibi tanımlaması ve yönetilmesi kolay olan fiziksel kısıtlar ve müşteri talepleri gibi tanımlaması, hesaplaması ya da yönetmesi zor olan fiziksel olmayan kısıtlar olmak üzere ikiye ayrılır (Huang, 1999). Sınıflandırmak açısından kısıt türlerine göre daha da detaylandırmak gerekirse pazar kısıt1, kapasite kısıtı, politik kısıt, direkt ilk madde kısıtı, lojistik kısıt, davranışsal kısıt ve yönetimsel kısıt olarak da sıralanabilir (İlhan, 2014: 12 16; Kaygusuz, 2005: 139; Tiryakigil, 2011: 63; Büyükyılmaz ve Gürkan, 2009: 182-184). Birçok türü bulunan kısıtların ortadan kaldırılabilmesi için kullanılan kısıtlar teorisinin uygulama süreci beş adımdan oluşmaktadır (Büyükyılmaz ve Gürkan, 2009: 185; İlhan, 2014: 4; Kaygusuz, 2011: 176; Huang, 1999). Bunlar;

- Kisitların tanımlanmasi

- Kısıtların etkin bir şekilde yönetilmesi

- Sistemin ikinci aşamada belirtilen amaca ulaşabilmesi için odaklanmas1

- Kisitların ortadan kaldırılması

- Kısıt ortadan kaldırıldığında tekrar birinci aşamaya dönülmesi.

Literatüre katk1 sunacağ düşünülen bu çalışmada hedef maliyetleme, değer analizi, kaizen maliyetleme ve kısıtlar teorisinin entegrasyonunun sağlanabilmesi için öncelikle bu yöntemlerin teorik olarak birlikte nasıl çalışabileceği detaylı olarak araştırılmıştır. Yapılan inceleme sonrasında izlenmesi gereken yolun öncelikle lojistik maliyetlerin, hedef maliyet yöntemi ve değer analizi entegrasyonu ile maliyet eksiği ve fazla maliyete katlanma noktasında analiz edilmesi olduğu tespit edilmiştir. Ancak bu analizin sonucu, hangi lojistik faaliyet ya da alt parçalarda ne tutarlarda iyileştirme yapılacağını gösteremeyecektir. $\mathrm{Bu}$ nedenle kaizen maliyetleme yöntemindeki tahsis oranları kullanılarak hedef maliyet yöntemiyle belirlenen iyileştirilme ihtiyacı olan maliyet kalemlerinin tutarları belirlenecek ve her kalemde ne kadar iyileştirme yapılması gerektiği saptanacaktır. Akabinde ise Kısıtlar teorisi yöntemi ile işletmenin lojistik faaliyet ve alt faaliyet parçalarında herhangi bir kısıtlar olup olmadığı incelenecek ve tespit edilen kısıtlar düzeltilerek işletmenin optimal maliyet yapısına ulaşması sağlanacaktır. 


\section{ARAŞTIRMA}

\section{Araștırmanın Amacı ve Önemi}

$\mathrm{Bu}$ araştırmanın amacı; işletmelerdeki lojistik maliyetlerin çağdaş maliyet yöntemlerinden hedef maliyetleme, değer analizi, kaizen maliyetleme ve kısıtlart teorisinin birbirine entegre edilerek kullanılması sonucunda nasıl azaltılacağını bir örnek uygulama ile ortaya koymaktır. Literatürde sadece bir yöntem kullanılarak incelenen lojistik maliyetler konusunun, bir maliyet yöntemi yerine 4 farklı çağdaş maliyet yönteminin entegrasyonu ile uygulamasının yapılması ise sektördeki uygulamacılar ile alan yazına olan katkısını göstermektedir.

\section{Araştırmanın Kapsamı ve Sınırlılıkları}

Araştırmanın uygulaması uluslararası ticaret yapan bir üretim işletmesinde vaka analizi yöntemi ile gerçekleştirilmiştir. Araştırma ile ilgili kısıtlardan ilkini; işletmenin ismi, alınan maliyet verilerinin detayı yöneticilerin talebi ve isteği üzerine rekabet ve ticari verilerin güvenliği açısından gizli tutulması oluşturmaktadır. Dört farklı çağdaş maliyet yönteminin entegrasyonu ile gerçekleştirilen model, işletmenin faaliyet süreçleri incelendikten sonra alt başlıkları itibarı ile işletmeye özgüdür. Bu nedenle modelin aynı şekilde başka bir işletmede uygulanamaması araştırmanın en önemli sınırlılığını oluşturmaktadır.

\section{Araştırmanın Yöntemi ve Örneklemi}

İşletmeler için çok önemli ve gizli olan bu verileri her işletmenin paylaşmak istememesi sebebiyle, araştırma kısmında uluslararası ticaret yapan sadece bir işletme örnek olarak seçilip, lojistik maliyetlere ilişkin veriler toplanarak vaka analizi yapılmıştır. $\mathrm{Bu}$ uygulama kapsamında silah fabrikası işletmesinin seçilmesinde; uluslararası ticaret yapması (\%97 ihracat yapması), lojistik faaliyetlerin stratejik açıdan önemli olması, detaylı olarak lojistik faaliyetlere ilişkin süreçleri ve verileri paylaşması önemli bir etken olmuştur. Dört farklı çağdaş maliyet yönteminin entegre bir şekilde kullanılarak lojistik maliyetlerde optimizasyonun nasıl yapılacağı işletmeden elde edilen bu veriler kullanılarak literatür kapsamında işletmenin lojistik faaliyetleri dikkate alınarak oluşturulan bir model ile ortaya konmuştur. Bu modelin oluşturulabilmesi için işletme yöneticileri ve lojistik faaliyetlerde çalışan kişiler ile yüz yüze görüşüldükten sonra tüm lojistik süreçler araştırmacı tarafından izlenmiştir. Ayrıca lojistik faaliyetler ile ilgili tüm çalışanlara (iç müşteri) değer analizi kapsamında lojistik faaliyetleri değerlendirmeleri için bir anket uygulanmıştır. Anket 2018 y1lında uygulandığı için Etik Kurul Onayı bulunmamaktadır. 


\section{Uygulama Yapılan İşletmenin Tanıtılması}

Uygulama yapılan işletme Konya'nın Huğlu/Beyşehir ilçesinde faaliyet gösteren bir silah fabrikasıdır. $4.000 \mathrm{~m} 2$ kapalı alanı bulunan işletmede 16 adet dikey eksenli CNC ve 4 adet yatay eksenli CNC ile üretim yapılmaktadır. İşletme süperpoze av tüfekleri ( 9 farklı ürün), otomatik av tüfekleri (21 farklı ürün), şarjörlü av tüfekleri (4 farklı ürün) ve pompalı av tüfekleri (15 farklı ürün) olmak üzere dört ana başlıkta toplamda 49 farklı ürünü sipariş üzerine üretmektedir. Ayrıca yaptığı Ar-Ge çalışmaları ile ürün çeşitleri arasına sürekli yenilerini eklemektedir. Yapılan üretimin yaklaşık \%97'si Amerika, Almanya, İsviçre, Rusya, Ukrayna, Güney Afrika, Gürcistan, Lübnan gibi dünyanın farklı ülkelerine ihraç etmektedir. İşletme sipariş üzerine üretim yaptığından, verilerin alındığı 2018 yılında işletmenin sadece 1 çeşit (85.000 adet) ürün üretip sattı̆̆ 1 görülmüştür. İşletme bu ürünleri üretirken birçok lojistik faaliyet kullanmakla birlikte, ağılıklı olarak temel lojistik faaliyetleri kullanmaktadır.

\section{Araştırma Bulgularının Değerlendirilmesi}

Aşağıda verilen maliyet bilgileri, işletmenin 2018 yılına ait kar zarar tablosu, finansal durum tablosu ve mizanı yanında işletme evrakları ve iş süreçleri detaylı olarak incelenmiş, işletme yöneticileri ile yüz yüze görüşüldükten sonra aşağıdaki gibi özetlenmiştir. İş yapılan alandaki rekabet düzeyinin çok yüksek olması nedeniyle işletme yönetiminin talebi üzerine ilgili belgeler ve maliyet verileri gizli tutulmuştur. Özet olarak bu araştırma kapsamında kullanılacak verilere ilişkin bilgiler aşağıda Tablo 1'de verilmiştir. 
Tablo 1. İşletme Verileri

\begin{tabular}{|c|c|c|c|}
\hline \multicolumn{2}{|c|}{ İSLETME VERILERI } & \multicolumn{2}{|c|}{ İŞLETME LOJISTIK FAALIYET VERİLERI } \\
\hline 2018 Satı̧ Gelirleri & $44.639 .155,70 €$ & 2018 Toplam Lojistik Maliyetler & $\begin{array}{r}3.797 .705, \\
84 €\end{array}$ \\
\hline $\begin{array}{l}2018 \text { Satılan Ürün } \\
\text { Maliyeti }\end{array}$ & $34.524 .598,50 €$ & 2018 Sipariş İșleme Toplam Maliyeti & $\begin{array}{r}379.770,5 \\
8 €\end{array}$ \\
\hline $\begin{array}{l}2018 \text { Ürün Birim } \\
\text { Fiili Satış Fiyatı } \\
\end{array}$ & $525,17 €$ & 2018 Ambalaj Toplam Maliyeti & $\begin{array}{r}949.426,4 \\
6 €\end{array}$ \\
\hline $\begin{array}{l}2018 \text { Ürün Birim } \\
\text { Fiili Maliyet }\end{array}$ & 406,17€ & 2018 Elleçleme Toplam Maliyeti & $\begin{array}{r}113.931,1 \\
8 \text { € }\end{array}$ \\
\hline $\begin{array}{l}2018 \text { Satılan Ürün } \\
\text { Sayı1S1 }\end{array}$ & 85.000 & 2018 Depolama Toplam Maliyeti & $\begin{array}{r}265.839,4 \\
1 €\end{array}$ \\
\hline 2018 Yilı Kar Marj1 & $\% 22,66$ & 2018 Taşıma Toplam Maliyeti & $\begin{array}{r}2.088 .738, \\
21 €\end{array}$ \\
\hline $\begin{array}{l}2018 \text { Y1lı Ürün } \\
\text { Birim Karı }\end{array}$ & $118,99 €$ & 2018 Y11 Ürün Birim Lojistik Maliyeti & $44,68 €$ \\
\hline \multicolumn{2}{|c|}{$\begin{array}{c}\text { ÜRÜN HEDEF MALIYYET } \\
\text { TAHMINLERİ } \\
\end{array}$} & \multicolumn{2}{|c|}{ LOJISTIK MALIYET TAHMINLERI } \\
\hline $\begin{array}{l}2019 \text { Tahmini Ürün } \\
\text { Satış1 }\end{array}$ & 94.000 & \multirow[b]{2}{*}{$\begin{array}{l}2019 \text { Yılı Tahmini Ürün Birim Lojistik } \\
\text { Maliyetler }\end{array}$} & \multirow[b]{2}{*}{$42,97 £$} \\
\hline $\begin{array}{l}2019 \text { Ürün Birim } \\
\text { Hedef Satış Fiyatı }\end{array}$ & $540,00 €$ & & \\
\hline $\begin{array}{l}2019 \text { Y1lı Ürün } \\
\text { Birim Hedef } \\
\text { Maliyeti }\end{array}$ & $390,64 €$ & \multirow[b]{2}{*}{$\begin{array}{l}2019 \text { Yılı Ürün Birim Lojistik Maliyetlerde } \\
\text { İndirilecek Tutar }\end{array}$} & \multirow[b]{2}{*}{$1,71 €$} \\
\hline $\begin{array}{l}2019 \text { Yılı Ürün } \\
\text { Birim Hedef Karı }\end{array}$ & 149,36£ & & \\
\hline $\begin{array}{l}2019 \text { Ürün Birim } \\
\text { Maliyet Düşürme } \\
\text { Hedefi }\end{array}$ & $15,53 €$ & \multirow{3}{*}{$\begin{array}{l}2019 \text { Ürün Birim Hedef Lojistik Maliyet } \\
\text { Düşürme Oranı }\end{array}$} & \multirow{3}{*}{$\% 3,82$} \\
\hline $\begin{array}{l}2019 \text { Hedef Kar } \\
\text { Marj1 }\end{array}$ & $\% 27,66$ & & \\
\hline $\begin{array}{l}2019 \text { Ürün Birim } \\
\text { Hedef Maliyet } \\
\text { Düsürme Oranı }\end{array}$ & $\% 3,82$ & & \\
\hline
\end{tabular}

Tablo 1'de işletmenin 2018 yılına ilişkin fiili maliyetleri ve satış rakamları ile 2019 yılına ilişkin tahmini satış adedi, fiyatı ve kâr marjı tutarları gösterilmektedir. İşletme lojistik maliyetler ve hedef maliyetler ile ilgili herhangi bir veri ayrışımına gitmediği için bu tutarlar araştırmacı tarafından oluşturulmuştur. Lojistik maliyetlerin neleri kapsadığı ve tüm tahmini verilerin nasıl hesaplandığ1 daha sonraki bölümlerde detaylı olarak anlatılacağından burada konuya ilişkin parçaların bütüncül olarak görülebilmesi açısından toplu olarak verilmiştir. 


\section{İşletmenin Ürün Birim Fïli Satış Fiyatının ve Maliyetinin Hesaplanması}

İşletmenin 2018 yılındaki ürün birim fiili satış fiyatı ile ürün birim fiili maliyeti ve ürün birim fiili karı aşağıdaki şekilde hesaplanmıştır.

$$
\begin{aligned}
& \text { Ürün Birim Fiili Satış Fiyatı }=\frac{2018 \text { Yllı Fiili Satış Gelirleri }}{2018 \text { Yllı Satılan Ürün Sayısı }} \\
& \text { Ürün Birim Fiili Satış Fiyatı }=\frac{44.639 .155,70 \mathrm{TL}}{85.000}=\mathbf{5 2 5 , 1 6} \mathbf{T L} \\
& \text { Ürün Birim Fiili Maliyeti }=\frac{2018 \text { Yılı Fiili Satılan Ürün Maliyeti }}{2018 \text { Yılı Satılan Ürün Sayısı }} \\
& \text { Ürün Birim Fiili Maliyeti }=\frac{34.524 .598,70 \mathrm{TL}}{85.000}=\mathbf{4 0 6 , 1 7} \text { TL }
\end{aligned}
$$

2018 Y1lı Ürün Birim Fiili Kârı = Ürün Birim Fiili Satış Fiyatı - Ürün Birim Fiili Maliyeti

2018 Y11 Ürün Birim Fiili Karı = 525,17 TL - 406,17 TL = 118,99 TL

İşletmenin 2018 yılında fiili kâr marjı, 2018 yılı ürün birim fiili kârının, ürün birim fiili satış fiyatına bölünmesi sonucunda \% 22,66 olarak hesaplanmıştır.

\section{İşletmenin Ürün Birim Lojistik Hedef Maliyetinin Hesaplanması}

İşletme yöneticileri ile yapılan görüşme sonrasında 2019 y1lı için hedef satış fiyatı 540 TL ve hedef kâr marj1 \%27,66 olarak belirlenmiştir. Buna göre, ürün birim hedef satış fiyatı ile ürün birim hedef kâr marjının çarpılması sonucunda işletmenin ürün birim hedef karı 149,36 TL olarak tespit edilmiştir. Hedef maliyet ise aşağıdaki gibi hesaplanmıştır:

Ürün Birim Hedef Maliyet $=$ Ürün Birim Hedef Satış Fiyat1 - Ürün Birim Hedef Kârı

Ürün Birim Hedef Maliyet $=540$ TL $-149,36$ TL $=\mathbf{3 9 0 , 6 4}$ TL

İşletmenin 2018 yılına ait ürün birim lojistik maliyeti ve ürün birim maliyet düşürme hedefi aşağıdaki gibi hesaplanır;

2018 Yllı Ürün Birim Fiili Lojistik Maliyet $\frac{2018 \text { Yılı Fiili Toplam Lojistik Maliyetler }}{2018 \text { Yılı Satılan Ürün Sayısı }}$

2018 Yılı Ürün Birim Fiili Lojistik Maliyet $=\frac{3.797 .705,84 T L}{85.000}=\mathbf{4 4 , 6 8 ~ T L}$ 
Ürün Birim Maliyet Düşürme Hedefi = Ürün Birim Maliyeti - Ürün Birim Hedef Maliyeti

Ürün Birim Maliyet Düşürme Hedefi = 406,17 TL - 390,64 TL = 15,53 TL

Ürün birim maliyet düşürme hedefinin 2018 yılı ürün birim maliyetine oranlanması ile ürün birim hedef maliyet düşürme oranına ulaşılır.

Ürün Birim Hedef Maliyet Düşürme Oranı Ürün Birim Maliyet Düşurrme Hedefi

Ürün Birim Hedef Maliyet Düşürme Oranı $=\frac{15,53 T L}{406,17 T L}=\% \mathbf{3 , 8 2}$

Bulunan bu ürün birim hedef maliyet düşürme oranı aynı zamanda lojistik maliyetlerde ürün başına düşürülmesi gereken oranı da göstermektedir. Buna göre işletmenin ürün birim lojistik maliyet düşürme hedefi aşağıdaki gibi hesaplanmıştır:

Ürün Birim Lojistik Maliyet Düşürme Hedefi $=($ Ürün Birim Lojistik Maliyetler * Ürün Birim Hedef Maliyet Düşürme Oranı)

Ürün Birim Lojistik Maliyet Düşürme Hedefi $=44,68$ TL * \%3,82 = 1,71 TL

Buna göre işletmenin 2019 yılı ürün birim toplam lojistik maliyet hedefi ise aşağıdaki gibi hesaplanır:

2019 Yılı Ürün Birim Toplam Lojistik Maliyet Hedefi = 2018 Y1lı Ürün Birim Fiili Lojistik Maliyet - Ürün Birim Lojistik Maliyet Düşürme Hedefi

2019 Y1lı Ürün Birim Toplam Lojistik Maliyet Hedefi $=44,68$ TL $-1,71$ TL

2019 Y1lı Ürün Birim Toplam Lojistik Maliyet Hedefi = 42,97 TL

\section{Hedef Maliyetin Ayrımlanması}

Hedef maliyetin ayrımlanması aşaması, işletmedeki lojistik faaliyetlerin fonksiyonlarının ve bu fonksiyonların parçalarının belirlenmesini ifade etmektedir. Bunun aşamaları ise aşağıda bölümlerde detaylı olarak açıklanmıştır.

\section{İşletmedeki Lojistik Faaliyetlerin ve Fonksiyonların Belirlenmesi}

Hedef maliyet kapsamında lojistik işlemlerin yerine getirilmesinde kullanılan bu faaliyetler fonksiyon olarak isimlendirilmektedir. Çalışma yapılan işletme, silah üretimi yapan ve ihracat ağırlıklı çalışan bir işletme olduğundan işletmenin 
lojistik fonksiyonları; sipariş işleme, ambalajlama, depolama, elleçleme ve taşıma olmak üzere 5'e ayrılmıştır.

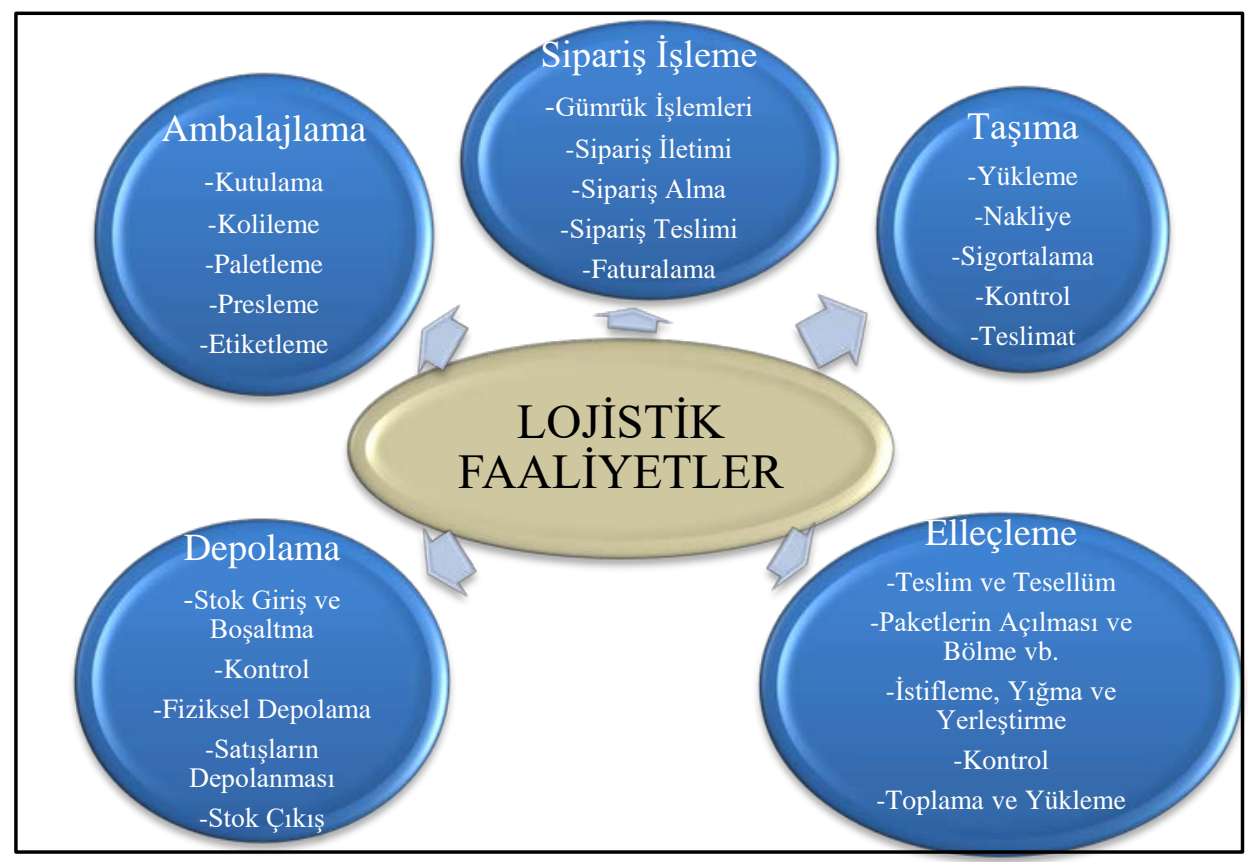

Şekil 1. İşletmenin Lojistik Fonksiyonları

\section{Lojistik Fonksiyonların Göreceli Öneminin Belirlenmesi}

Araştırmada uygulama yapılan işletmenin lojistik faaliyetleri, direkt ilk maddenin depoya alınması ile başlayıp, nihai ürünün müşteriye ulaşıncaya kadar işletmede ya da işletme dışında gerçekleşen fonksiyonlardan oluşmaktadır. Araştırmada alt fonksiyonlar daha çok iç müşteriler yani çalışanların bu süreçlerde derinlemesine bilgi sahibi olmaları nedeniyle işletmede lojistik faaliyetler ile ilgili kapsamda çalışanlara anket uygulanmıştır. İşletmenin lojistik faaliyetlerinde çalışan 11 kişilik tüm personeli kapsayan bu anket ile lojistik fonksiyonların personel tarafından önem derecesine göre sıralanması istenmiştir. Aşağıdaki tablolarda lojistik personelin verdikleri cevaplara göre alt fonksiyonların önem dereceleri gösterilmiştir. 
Tablo 2. Sipariş İşleme Alt Fonksiyonları ve Görece Önem Dereceleri

\begin{tabular}{|c|c|c|}
\hline \multicolumn{3}{|c|}{ Sipariş İşleme Alt Fonksiyonları } \\
\hline \multirow[b]{2}{*}{ Fonksiyonlar } & \multicolumn{2}{|c|}{ Görece Önem Dereceleri } \\
\hline & Puan & $\%$ \\
\hline Gümrük İşlemleri & 43 & 26,06 \\
\hline Sipariş İletimi & 20 & 12,12 \\
\hline Sipariş Alma & 36 & 21,82 \\
\hline Sipariş Teslimi & 38 & 23,03 \\
\hline Faturalama & 28 & 16,97 \\
\hline Toplam & 165 & 100 \\
\hline \multicolumn{3}{|c|}{ Ambalajlama Alt Fonksiyonları } \\
\hline \multirow[b]{2}{*}{ Fonksiyonlar } & \multicolumn{2}{|c|}{ Görece Önem Dereceleri } \\
\hline & Puan & $\%$ \\
\hline Kutulama & 44 & 26,67 \\
\hline Kolileme & 40 & 24,24 \\
\hline Paletleme & 30 & 18,18 \\
\hline Presleme & 27 & 16,36 \\
\hline Etiketleme & 24 & 14,55 \\
\hline Toplam & 165 & 100 \\
\hline \multicolumn{3}{|c|}{ Depolama Alt Fonksiyonları } \\
\hline \multirow[b]{2}{*}{ Fonksiyonlar } & \multicolumn{2}{|c|}{ Görece Önem Dereceleri } \\
\hline & Puan & $\%$ \\
\hline Stok Giriş ve Boşaltma & 32 & 19,39 \\
\hline Kontrol & 34 & 20,61 \\
\hline Fiziksel Depolama & 30 & 18,18 \\
\hline Satışların Depolanması & 31 & 18,79 \\
\hline Stok Çıkış & 38 & 23,03 \\
\hline Toplam & 165 & 100 \\
\hline \multicolumn{3}{|c|}{ Elleçleme Alt Fonksiyonları } \\
\hline \multirow[b]{2}{*}{ Fonksiyonlar } & \multicolumn{2}{|c|}{ Görece Önem Dereceleri } \\
\hline & Puan & $\%$ \\
\hline Teslim ve Tesellüm & 33 & 20 \\
\hline Paketlerin Açılması ve Bölme vb. & 38 & 23,03 \\
\hline İstifleme, Yığma, Yerleştirme & 23 & 13,94 \\
\hline Kontrol & 36 & 21,82 \\
\hline Toplama ve Yükleme & 35 & 21,21 \\
\hline Toplam & 165 & 100 \\
\hline \multicolumn{3}{|c|}{ Taşıma Alt Fonksiyonları } \\
\hline \multirow[b]{2}{*}{ Fonksiyonlar } & \multicolumn{2}{|c|}{ Görece Önem Dereceleri } \\
\hline & Puan & $\%$ \\
\hline Yükleme & 29 & 17,58 \\
\hline
\end{tabular}




\begin{tabular}{|l|c|c|} 
Nakliye & 51 & 30,91 \\
\hline Sigortalama & 44 & 26,67 \\
\hline Kontrol & 18 & 10,91 \\
\hline Teslimat & 23 & 13,94 \\
\hline Toplam & $\mathbf{1 6 5}$ & $\mathbf{1 0 0}$ \\
\hline
\end{tabular}

Sipariş işlemede en çok önemsenen fonksiyonun gümrük işlemleri olmasında ürünlerin neredeyse tamamının ihraç edilmesinin büyük oranda etkili olduğunu söylemek mümkündür İç müşteriler yani çalışanlar ambalajlamada en çok kutulama fonksiyonuna ve en az da etiketleme fonksiyonuna önem vermektedir. Depolamada, oranlar birbirine çok yakın olmakla birlikte iç müşterilerin en çok önem verdikleri fonksiyonun stok çıkışı olduğu, en az önem verdikleri fonksiyonun ise fiziksel depolama olduğu görülmektedir. Elleçlemede ise iç müşteriler en çok paketlerin açılması ve bölme vb. fonksiyonuna ve en az da istifleme, yı̆̆ma, yerleştirme fonksiyonuna önem vermektedirler. Son olarak taşımada önem derecesi en yüksek fonksiyonlar nakliye ve sigortalama iken diğer fonksiyonların önem dereceleri bu iki fonksiyona göre çok daha düşüktür.

\section{Lojistik Fonksiyonların Alt Parçalarının Belirlenmesi}

Hizmet ya da ürünün üretilebilmesi için gerçekleştirilen faaliyetler, lojistik fonksiyonların alt parçalarını oluşturmaktadır. İşletmede araştırma yapılan alan sadece lojistik maliyetleri kapsadığı için lojistiğin özellikleri dikkate alınarak belirlenen 5 ana fonksiyonun alt parçaları şekil $2^{\prime} \mathrm{de}^{2}$ özetlenmiştir.

\footnotetext{
${ }^{2}$ Çalışmada hesaplanan maliyet verileri işletmenin tüm maliyetlerini değil sadece lojistik maliyetlerini göstermektedir. Şekil $4.2^{\prime}$ 'de görüleceği üzere amortisman giderleri bu maliyetler içinde yer almamaktadır. Lojistik faaliyetlere yönelik binaların kiralık olması nedeniyle, bunun yanında kullanılan forkliftlerden birinin amortisman ayırma süresi dolması ve diğer forkliftte ise çok düşük bir tutara tekabül eden amortisman gideri olması nedeniyle ilgili tutar ayrı bir kalem olarak alınmamış olup diğer faaliyetlere dağıtılmıştır.
} 


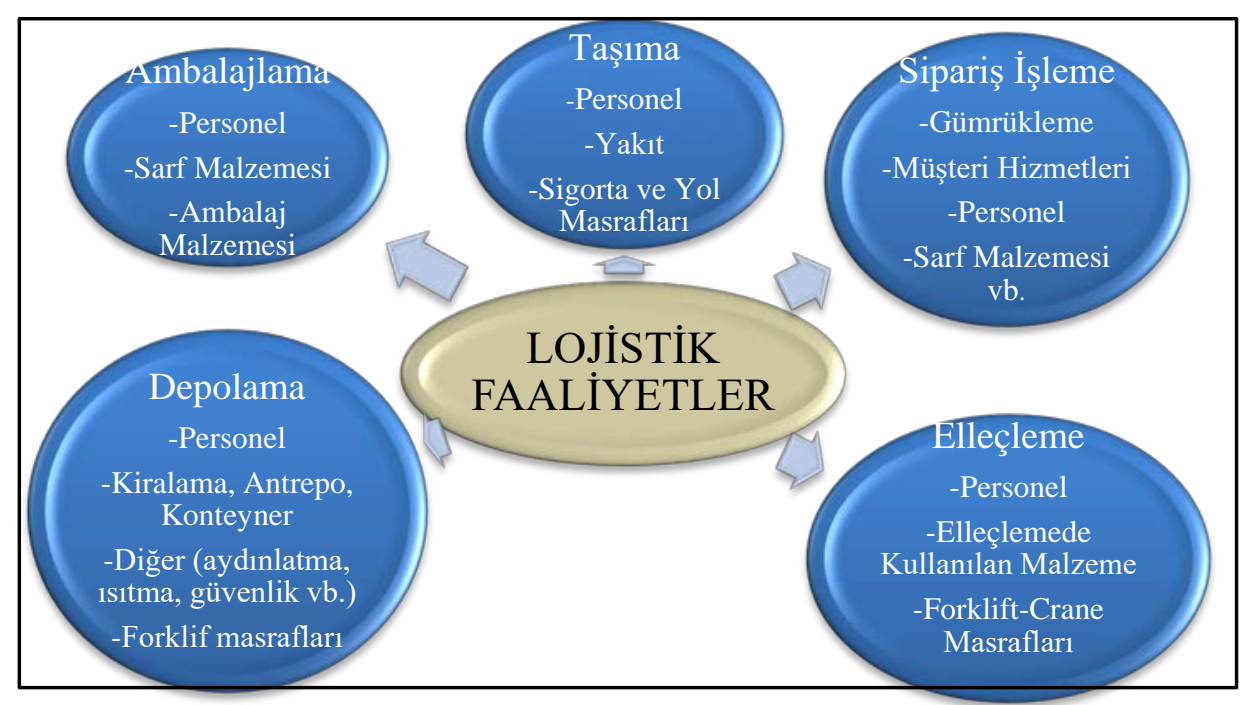

Şekil 2. İşletmenin Lojistik Fonksiyonlarının Alt Parçaları

\section{Lojistik Fonksiyonlarının Alt Parça Maliyetlerinin Hesaplanması}

Uygulama yapılan işletmenin muhasebe sistemi kapsamında bu veriler tutulmadığından, belgelerin ve lojistik sürecin incelenmesine ek olarak lojistik faaliyetlerde çalişan kişiler ve yöneticilerle de görüşüldükten sonra lojistik fonksiyonların alt parçalarının maliyetleri araştırmacı tarafından hesaplanmıştır.

Tablo 3. Sipariş İşleme Fonksiyonu Alt Parçaları

\begin{tabular}{|l|c|c|}
\hline Sipariş İşleme Fonksiyonu Alt Parçaları \\
\hline Parçalar & Parçanın Maliyeti (TL) & Maliyet Payı \% \\
\hline Gümrükleme & $135.300,00$ & 35,63 \\
\hline Müşteri Hizmetleri & $90.270,58$ & 23,77 \\
\hline Personel & $126.200,00$ & 33,23 \\
\hline Sarf Malzemesi vb. & $28.000,00$ & 7,37 \\
\hline Toplam & $\mathbf{3 7 9 . 7 7 0 , 5 8}$ & $\mathbf{1 0 0}$ \\
\hline Ambalajlama Fonksiyonu Alt Parçaları & \multicolumn{2}{|c|}{} \\
\hline Parçalar & Parçanın Maliyeti (TL) & Maliyet Payı \% \\
\hline Personel & $73.062,00$ & 7,70 \\
\hline Sarf Malzemesi & $49.364,46$ & 5,20 \\
\hline Ambalaj Malzemesi & $827.000,00$ & 87,11 \\
\hline Toplam & $\mathbf{9 4 9 . 4 2 6 , 4 6}$ & $\mathbf{1 0 0}$ \\
\hline Elleçleme Fonksiyonu Alt Parçaları & \multicolumn{2}{|}{} \\
\hline
\end{tabular}




\begin{tabular}{|l|r|c|}
\hline Parçalar & Parçanın Maliyeti (TL) & Maliyet Payı \% \\
\hline Personel & $24.354,00$ & 21,38 \\
\hline Elleçlemede kullanılan malzeme & $3.547,18$ & 3,11 \\
\hline Forklift-crane masrafları & $86.030,00$ & 75,51 \\
\hline Toplam & $\mathbf{1 1 3 . 9 3 1 , 1 8}$ & $\mathbf{1 0 0}$ \\
\hline Depolama Fonksiyonu Alt Parçaları & Parçanın Maliyeti (TL) & Maliyet Payı \% \\
\hline Parçalar & $48.708,00$ & 18,32 \\
\hline Personel & $9.776,41$ & 3,68 \\
\hline Kiralama antrepo konteyner & $21.267,00$ & 8 \\
\hline Diğer (Aydınlatma, ssıtma, güvenlik vb.) & $186.088,00$ & 70 \\
\hline Forklift-crane masrafları & $\mathbf{2 6 5 . 8 3 9 , 4 1}$ & $\mathbf{1 0 0}$ \\
\hline Toplam & \multicolumn{3}{|c|}{} \\
\hline Taşıma Fonksiyonu Alt Parçaları & Parçanın Maliyeti (TL) & Maliyet Payı \% \\
\hline Parçalar & $98.400,00$ & 4,71 \\
\hline Personel & $3.635 .253,21$ & 78,29 \\
\hline Yakıt & $\mathbf{2 . 0 8 8 . 7 3 8 , 2 1}$ & $\mathbf{1 0 0}$ \\
\hline Sigorta ve yol masrafları & & 17 \\
\hline Toplam &
\end{tabular}

\section{Lojistik Faaliyetleri Oluşturan Parçaların Görece Öneminin Belirlenmesi}

Hedef maliyetin ayrımlanması için lojistik fonksiyonların göreceli önem dereceleri ile bunların alt parçaları bir matris ile karşılaştırılmıştır. Lojistik faaliyetleri oluşturan temel fonksiyonlar ile parçaları içeren 5 farklı matris ortaya çıkmıştır. $\mathrm{Bu}$ matrislerin ve bunların görece önem derecelerinin nasıl hesaplandığı aşağıda açıklanmıştır. 
Tablo 3. Sipariş İşleme Alt Parçalarının Görece Önem Dereceleri

\begin{tabular}{|c|c|c|c|c|c|c|}
\hline \multirow{3}{*}{$\begin{array}{l}\text { Sipariş } \\
\text { İşleme } \\
\text { Alt } \\
\text { Parçaları }\end{array}$} & \multicolumn{5}{|c|}{ Sipariş İșleme Alt Fonksiyonlarının Görece Önem Dereceleri } & \multirow{3}{*}{\begin{tabular}{|c} 
Parçaları \\
Görece \\
Önemi \\
$\%$ \\
\end{tabular}} \\
\hline & $\begin{array}{l}\text { Gümrük } \\
\text { İşlemleri }\end{array}$ & $\begin{array}{l}\text { Sipariş } \\
\text { İletimi }\end{array}$ & $\begin{array}{c}\begin{array}{c}\text { Sipariş } \\
\text { alma }\end{array} \\
\end{array}$ & $\begin{array}{l}\text { Sipariş } \\
\text { teslimi }\end{array}$ & Faturalama & \\
\hline & $26,06 \%$ & $12,12 \%$ & $21,82 \%$ & $23,03 \%$ & $16,97 \%$ & \\
\hline Gümrükleme & $70 \%$ & $5 \%$ & $5 \%$ & $20 \%$ & $20 \%$ & $27,94 \%$ \\
\hline $\begin{array}{c}\text { Müşteri } \\
\text { Hizmetleri } \\
\end{array}$ & $10 \%$ & $70 \%$ & $80 \%$ & $65 \%$ & $5 \%$ & $44,36 \%$ \\
\hline Personel & $15 \%$ & $20 \%$ & $10 \%$ & $10 \%$ & $55 \%$ & $20,15 \%$ \\
\hline $\begin{array}{c}\text { Sarf } \\
\text { Malzemesi } \\
\text { vb. }\end{array}$ & $5 \%$ & $5 \%$ & $5 \%$ & $5 \%$ & $20 \%$ & $7,55 \%$ \\
\hline TOPLAM & $100 \%$ & $100 \%$ & $100 \%$ & $100 \%$ & $100 \%$ & $100 \%$ \\
\hline Ambalajlam & \multicolumn{5}{|c|}{ Ambalajlama Alt Fonksiyonlarının Görece Önem Dereceleri } & \multirow{3}{*}{$\begin{array}{c}\text { Parçaları } \\
\text { Görece } \\
\text { Önemi } \\
\%\end{array}$} \\
\hline $\begin{array}{c}\text { a } \\
\text { Alt }\end{array}$ & Kutulama & Kolileme & Paletleme & Presleme & Etiketleme & \\
\hline Parçaları & $26,67 \%$ & $24,24 \%$ & $18,18 \%$ & $16,36 \%$ & $14,55 \%$ & \\
\hline Personel & $20 \%$ & $20 \%$ & $20 \%$ & $30 \%$ & $20 \%$ & $21,64 \%$ \\
\hline $\begin{array}{c}\text { Sarf } \\
\text { Malzemesi }\end{array}$ & $5 \%$ & $10 \%$ & $5 \%$ & $10 \%$ & $10 \%$ & $7,76 \%$ \\
\hline $\begin{array}{c}\text { Ambalaj } \\
\text { Malzemesi }\end{array}$ & $75 \%$ & $70 \%$ & $75 \%$ & $60 \%$ & $70 \%$ & $70,61 \%$ \\
\hline TOPLAM & $100 \%$ & $100 \%$ & $100 \%$ & $100 \%$ & $100 \%$ & $100 \%$ \\
\hline \multirow{3}{*}{$\begin{array}{l}\text { Elleçleme } \\
\text { Alt } \\
\text { Parçaları } \\
\end{array}$} & Elleçle & e Alt Fonks & yonlarının $\mathrm{G}$ & örece Önem & ereceleri & \multirow{3}{*}{$\begin{array}{c}\text { Parçaları } \\
\text { Görece } \\
\text { Önemi } \\
\%\end{array}$} \\
\hline & $\begin{array}{l}\text { Teslim ve } \\
\text { Tesellüm } \\
\end{array}$ & $\begin{array}{c}\text { Paketlerin } \\
\text { Açılması } \\
\text { ve Bölme } \\
\text { vb. } \\
\end{array}$ & $\begin{array}{l}\text { İstifleme, } \\
\text { Yığma, } \\
\text { Yerleştirme } \\
\end{array}$ & Kontrol & $\begin{array}{c}\text { Toplama ve } \\
\text { Yükleme }\end{array}$ & \\
\hline & $20,00 \%$ & $23,03 \%$ & $13,94 \%$ & $21,82 \%$ & $21,21 \%$ & \\
\hline Personel & $90 \%$ & $85 \%$ & $55 \%$ & $100 \%$ & $30 \%$ & $73,42 \%$ \\
\hline $\begin{array}{c}\text { Elleçlemede } \\
\text { kul. malzeme } \\
\end{array}$ & $0 \%$ & $5 \%$ & $5 \%$ & $0 \%$ & $0 \%$ & $1,85 \%$ \\
\hline $\begin{array}{c}\text { Forklift- } \\
\text { crane } \\
\text { masrafları }\end{array}$ & $10 \%$ & $10 \%$ & $40 \%$ & $0 \%$ & $70 \%$ & $24,73 \%$ \\
\hline \multirow[t]{3}{*}{ TOPLAM } & $100 \%$ & $100 \%$ & $100 \%$ & $100 \%$ & $100 \%$ & $100 \%$ \\
\hline & \multicolumn{5}{|c|}{ Depolama Görece Önem Dereceleri } & \multirow{2}{*}{$\begin{array}{c}\text { Parçaların } \\
\text { Görece } \\
\text { Önemi } \\
\%\end{array}$} \\
\hline & $\begin{array}{c}\text { Stok Giriş, } \\
\text { Boşaltma }\end{array}$ & Kontrol & \begin{tabular}{|c|} 
Fiziksel \\
Depolama
\end{tabular} & $\begin{array}{c}\text { Satışların } \\
\text { Depolanma } \\
\text { s1 } \\
\end{array}$ & Stok Çıkış & \\
\hline $\begin{array}{c}\text { Depolama } \\
\text { Alt } \\
\text { Parçaları }\end{array}$ & $19,39 \%$ & $20,61 \%$ & $18,18 \%$ & $18,79 \%$ & $23,03 \%$ & \\
\hline Personel & $30 \%$ & $80 \%$ & $25 \%$ & $40 \%$ & $40 \%$ & $43,58 \%$ \\
\hline
\end{tabular}




\begin{tabular}{|c|c|c|c|c|c|c|}
\hline $\begin{array}{l}\text { Kiralama } \\
\text { antrepo } \\
\text { konteyner }\end{array}$ & $15 \%$ & $10 \%$ & $5 \%$ & $5 \%$ & $15 \%$ & $10,27 \%$ \\
\hline $\begin{array}{c}\text { Diğer } \\
\text { (Aydınlatma, } \\
\text { 1sitma, } \\
\text { güvenlik vb.) }\end{array}$ & $20 \%$ & $5 \%$ & $10 \%$ & $20 \%$ & $5 \%$ & $11,64 \%$ \\
\hline $\begin{array}{l}\text { Forklift- } \\
\text { crane } \\
\text { masrafları }\end{array}$ & $35 \%$ & $5 \%$ & $60 \%$ & $35 \%$ & $40 \%$ & $34,52 \%$ \\
\hline \multirow[t]{2}{*}{ TOPLAM } & $100 \%$ & $100 \%$ & $100 \%$ & $100 \%$ & $100 \%$ & $100 \%$ \\
\hline & \multicolumn{5}{|c|}{ Taşıma Alt Fonksiyonlarının Görece Önem Dereceleri } & Parçaların \\
\hline \multirow{2}{*}{$\begin{array}{c}\text { Taşıma } \\
\text { Alt } \\
\text { Parçaları } \\
\end{array}$} & Yükleme & Nakliye & $\begin{array}{c}\text { Sigortalam } \\
\mathrm{a}\end{array}$ & Kontrol & Teslimat & $\begin{array}{c}\text { Görece } \\
\text { Önemi } \\
\%\end{array}$ \\
\hline & $17,58 \%$ & $30,91 \%$ & $26,67 \%$ & $10,91 \%$ & $13,94 \%$ & \\
\hline Personel & $60 \%$ & $20 \%$ & $10 \%$ & $95 \%$ & $95 \%$ & $43,00 \%$ \\
\hline Yakit & $30 \%$ & $65 \%$ & $0 \%$ & $5 \%$ & $5 \%$ & $26,61 \%$ \\
\hline $\begin{array}{c}\text { Sigorta ve } \\
\text { yol } \\
\text { masrafları } \\
\end{array}$ & $10 \%$ & $15 \%$ & $90 \%$ & $0 \%$ & $0 \%$ & $30,39 \%$ \\
\hline TOPLAM & $100 \%$ & $100 \%$ & $100 \%$ & $100 \%$ & $100 \%$ & $100 \%$ \\
\hline
\end{tabular}

Yukarıda tabloda sipariş işleme fonksiyonunun alt parçalarına ilişkin matris görülmektedir. Tabloda koyu renk ile işaretlenmiş olan kısımlar sipariş işleme fonksiyonunun alt fonksiyonları olan gümrük işlemleri, sipariş iletimi, sipariş alma, sipariş teslimi ve faturalamanın görece önem derecelerini göstermektedir. $\mathrm{Bu}$ önem dereceleri, iç müşterilere yapılan anket sonucunda hesaplanan değer analizi sonuçlarıdır. Alt parçaların her bir alt fonksiyon ile kesiştiği hücrelerdeki yüzdeler ise silah fabrikası yöneticileri ile yapılan yüz yüze görüşme sonucunda elde edilen yüzdeleri göstermektedir. En son sütunda görülen parçaların görece önem derecelerinin nasıl hesaplandığı örnek olarak gümrükleme parçası üzerinden açıklanacak olursa;

Gümrükleme Parçası Görece Önem Derecesi $=($ Gümrük işlemeleri fonksiyonu önem derecesi * gümrükleme parçasındaki payı) + (sipariş iletimi fonksiyonu önem derecesi * gümrükleme parçasındaki payı) + (sipariş alma fonksiyonu önem derecesi $*$ gümrükleme parçasındaki payı) $+($ sipariş teslimi fonksiyonu önem derecesi $*$ gümrükleme parçasındaki payı) + (faturalama fonksiyonu önem derecesi * gümrükleme parçasındaki payı)

Gümrükleme Parças1 Görece Önem Derecesi $=(\% 26,06 * \% 70)+$ $(\% 12,12 * \% 5)+(\% 21,82 * \% 5)+(\% 23,03 * \% 20)+(\% 16,97 * \% 20)=\% 27,94$. 
Müşteri Hizmetleri Parças1 Görece Önem Derecesi $=(\% 26,06 * \% 10)+$ $(\% 12,12 * \% 70)+(\% 21,82 * \% 80)+(\% 23,03 * \% 65)+(\% 16,97 * \% 5)=\% 44,36$.

Personel Parçasının Görece Önem Derecesi $=(\% 26,06 * \% 15)+$ $(\% 12,12 * \% 20)+(\% 21,82 * \% 10)+(\% 23,03 * \% 10)+(\% 16,97 * \% 55)=\% 20,15$.

Sarf Malzemesi vb. Parçasının Görece Önem Derecesi $=(\% 26,06 * \% 5)+$ $(\% 12,12 * \% 5)+(\% 21,82 * \% 5)+(\% 23,03 * \% 5)+(\% 16,97 * \% 20)=\% 7,55$,

olarak hesaplanır.

\section{Parçalara İlişkin Hedef Maliyet Endeksinin Hesaplanmast ve Optimizasyonu}

Parçaların hedef maliyet endeksinin hesaplanabilmesi için daha önceki aşamalarda bulunan parçaların görece önem dereceleri ile her bir parçanın maliyet paylarının birbirine bölünmesi gerekmektedir. Parçaların hedef maliyet endekslerine ilişkin hesaplamalar aşağıdaki formül kullanılarak gerçekleştirilmiştir:

$$
\text { Parçanın Değer Endeksi }=\frac{\text { Parçanın Görece Önem Derecesi }}{\text { Parçanın Maliyet Ağırlı̆̆ } l}
$$

Yukarıda belirtilen formüle göre bulunan hedef maliyet değer endeksinin 1 olması istenmektedir. Bulunan sonucun 1'den büyük olması, müşteriler (iç müşteriler) tarafından önem verilen fonksiyonlara yeterince kaynak ayrılmadığ 1 veya maliyetinin az olduğu; 1'den küçük olması ise müşteriler (iç müşteriler) tarafından önem verilmeyen bir fonksiyon için çok fazla kaynak ayrıldığını ya da daha fazla maliyete katlanıldığını göstermektedir. Her bir alt parça için hesaplanan değer endeksi aşağıdaki tabloda gösterilmiştir:

Tablo 5. Sipariş İşleme Alt Parçalarının Hedef Maliyet Endeksleri

\begin{tabular}{|c|c|c|c|}
\hline \multicolumn{4}{|c|}{ Sipariş İşleme Parçalarının Hedef Maliyet Endeksleri } \\
\hline Parçalar & $\begin{array}{l}\text { Parçanın } \\
\text { Görece } \\
\text { Önemi } \\
\end{array}$ & \begin{tabular}{|l|} 
Parçanın \\
Maliyet \\
Ağırlığı \\
\end{tabular} & $\begin{array}{c}\text { Parçanın } \\
\text { Maliyet } \\
\text { Endeksi }\end{array}$ \\
\hline Gümrükleme & $28 \%$ & $36 \%$ & 0,78 \\
\hline Müşteri Hizmetleri & $44 \%$ & $24 \%$ & 1,87 \\
\hline Personel & $20 \%$ & $33 \%$ & 0,61 \\
\hline Sarf Malzemesi vb. & $8 \%$ & $7 \%$ & 1,02 \\
\hline \multicolumn{4}{|c|}{ Ambalajlama Parçalarının Hedef Maliyet Endeksleri } \\
\hline Parçalar & $\begin{array}{l}\text { Parçanın } \\
\text { Görece } \\
\text { Önemi }\end{array}$ & $\begin{array}{l}\text { Parçanın } \\
\text { Maliyet } \\
\text { Ağırlığı }\end{array}$ & $\begin{array}{c}\text { Parçanın } \\
\text { Maliyet } \\
\text { Endeksi }\end{array}$ \\
\hline
\end{tabular}




\begin{tabular}{|c|c|c|c|}
\hline Personel & $22 \%$ & $8 \%$ & 2,81 \\
\hline Sarf Malzemesi & $8 \%$ & $5 \%$ & 1,49 \\
\hline Ambalaj Malzemesi & $71 \%$ & $87 \%$ & 0,81 \\
\hline \multicolumn{4}{|c|}{ Elleçleme Parçalarının Hedef Maliyet Endeksleri } \\
\hline Parçalar & \begin{tabular}{|l|} 
Parçanın \\
Görece \\
Önemi \\
\end{tabular} & \begin{tabular}{|l|} 
Parçanın \\
Maliyet \\
Ağırlığı \\
\end{tabular} & $\begin{array}{c}\text { Parçanın } \\
\text { Maliyet } \\
\text { Endeksi } \\
\end{array}$ \\
\hline Personel & $73 \%$ & $21 \%$ & 3,43 \\
\hline Elleçlemede kullanılan malzeme & $2 \%$ & $3 \%$ & 0,59 \\
\hline Forklift-crane masrafları & $25 \%$ & $76 \%$ & 0,33 \\
\hline \multicolumn{4}{|c|}{ Depolama Parçalarının Hedef Maliyet Endeksleri } \\
\hline Parçalar & $\begin{array}{l}\text { Parçanın } \\
\text { Görece } \\
\text { Önemi }\end{array}$ & $\begin{array}{l}\text { Parçanın } \\
\text { Maliyet } \\
\text { Ağırlığı }\end{array}$ & $\begin{array}{c}\text { Parçanın } \\
\text { Maliyet } \\
\text { Endeksi }\end{array}$ \\
\hline Personel & $44 \%$ & $18 \%$ & 2,38 \\
\hline Kiralama antrepo konteyner & $10 \%$ & $4 \%$ & 2,79 \\
\hline Diğer (Aydınlatma, ısıtma, güvenlik vb.) & $12 \%$ & $8 \%$ & 1,45 \\
\hline Forklift-crane masrafları & $35 \%$ & $70 \%$ & 0,49 \\
\hline \multicolumn{4}{|c|}{ Taşıma Parçalarının Hedef Maliyet Endeksleri } \\
\hline Parçalar & \begin{tabular}{|l|} 
Parçanın \\
Görece \\
Önemi \\
\end{tabular} & $\begin{array}{l}\text { Parçanın } \\
\text { Maliyet } \\
\text { Ağırlığı } \\
\end{array}$ & $\begin{array}{c}\text { Parçanın } \\
\text { Maliyet } \\
\text { Endeksi } \\
\end{array}$ \\
\hline Personel & $43 \%$ & $5 \%$ & 9,13 \\
\hline Yakit & $27 \%$ & $78 \%$ & 0,34 \\
\hline Sigorta ve yol masrafları & $30 \%$ & $17 \%$ & 1,79 \\
\hline
\end{tabular}

Hangi parçalarda maliyet düşürülmesi gerektiği ya da maliyetlerin sabit tutularak fonksiyonların geliştirilmesi gerektiği yukarıdaki tabloda tespit edilmiştir. İşletmenin hesaplanan parça önem endeksine göre uygulaması gereken stratejiler Tablo 6' da kısaca özetlenmiştir.

Tablo 6. Parça Önem Endeksine Göre Lojistik Alt Parçalarda Uygulanacak Stratejiler

\begin{tabular}{|c|l|c|l|}
\hline $\begin{array}{c}\text { Lojistik } \\
\text { Fonksiyonlar }\end{array}$ & Lojistik Fonksiyon Alt Parçaları & $\begin{array}{c}\text { Parçanın } \\
\text { Önem } \\
\text { Endeksi }\end{array}$ & Gerekli Stratejiler \\
\hline \multirow{3}{*}{ Sipariş İşleme } & Gümrükleme İşlemleri & 0,78 & Maliyeti Düsür \\
\cline { 2 - 4 } & Müşteri Hizmetleri & 1,87 & $\begin{array}{l}\text { Fonksiyonelliği } \\
\text { Arttır }\end{array}$ \\
\cline { 2 - 5 } & Personel & 0,61 & Maliyeti Düşür \\
\hline
\end{tabular}




\begin{tabular}{|l|l|c|l|} 
& Sarf Malzemesi vb. & 1,02 & $\begin{array}{l}\text { Fonksiyonelliği } \\
\text { Arttır }\end{array}$ \\
\hline \multirow{5}{*}{ Ambalajlama } & Personel & 2,81 & $\begin{array}{l}\text { Fonksiyonelliği } \\
\text { Arttır }\end{array}$ \\
\cline { 2 - 4 } & Sarf Malzemesi & 1,49 & $\begin{array}{l}\text { Fonksiyonelliği } \\
\text { Arttır }\end{array}$ \\
\cline { 2 - 4 } & Ambalaj Malzemesi & 0,81 & Maliyeti Düşür \\
\hline \multirow{5}{*}{ Elleçleme } & Personel & 3,43 & $\begin{array}{l}\text { Fonksiyonelliği } \\
\text { Arttır }\end{array}$ \\
\cline { 2 - 4 } & Elleçlemede kullanılan malzeme & 0,59 & Maliyeti Düşür \\
\cline { 2 - 4 } & Forklift-crane masrafları & 0,33 & Maliyeti Düşür \\
\hline \multirow{5}{*}{ Depolama } & Kersonel & 2,38 & $\begin{array}{l}\text { Fonksiyonelliği } \\
\text { Arttır }\end{array}$ \\
\cline { 2 - 4 } & Kiralama antrepo konteyner & 2,79 & $\begin{array}{l}\text { Fonksiyonelliği } \\
\text { Arttır }\end{array}$ \\
\cline { 2 - 4 } & Diğer (Aydınlatma, ssıtma, güvenlik vb.) & 1,45 & $\begin{array}{l}\text { Fonksiyonelliği } \\
\text { Arttır }\end{array}$ \\
\cline { 2 - 4 } & Forklift-crane masrafları & 0,49 & Maliyeti Düşür \\
\hline \multirow{5}{*}{ Taşıma } & Personel & 9,13 & $\begin{array}{l}\text { Fonksiyonelliği } \\
\text { Arttır }\end{array}$ \\
\cline { 2 - 4 } & Yakıt & 0,34 & Maliyeti Düşür \\
\cline { 2 - 4 } & Sigorta ve yol masrafları & 1,79 & $\begin{array}{l}\text { Fonksiyonelliği } \\
\text { Arttır }\end{array}$ \\
\hline
\end{tabular}

Hedef maliyetin ayrımlanmasının son aşaması olan parçaların hedef maliyet endekslerinin hesaplanmasından sonra maliyetlerin en uygun hale getirilebilmesi için parçaların maliyet endekslerinin optimize edilmesi gerekmektedir. Bulunan maliyet endeksleri parçaların ve fonksiyonların hangilerinde fazla ya da az maliyete katlanıldığını ve bu durumun değiştirilmesinin gerekliliğini göstermekle birlikte bunun nasıl yapılacağına ve hangi tutarda olacağına açıklık getirmemektedir. Bir sonraki aşamada kaizen maliyetleme yöntemi ile hangi parçalarda ne kadar maliyet düşürülmesi gerektiği hesaplanmalı ve bu indirimlerin toplam1 2019 y1lı hedeflenen toplam lojistik maliyet düşürme hedefi kadar olmalidir.

\section{Hedef Maliyetin Optimizasyonunda Kaizen Maliyetlemenin Kullanılması}

Hedef maliyetlemenin, kaizen maliyetleme ile entegre olarak kullanılması durumunda maliyetlerin düşürülmesi ve ürün/hizmet fonksiyonelliğinin arttırılması açısından birbirini tamamladıkları görülecektir. Hedef maliyetlemede hangi fonksiyonun hangi parçasında maliyet değişimi yapılacağı görünse de bu maliyetlerin ne kadar azaltılacağı belirlenememektedir. Bu noktadan hareketle kaizen maliyetleme ile ne kadar maliyet düşürülmesi gerektiği tespit edilebilir. 
Maliyet optimizasyonu açısından kaizen maliyetleme yönteminin uygulanması sürecinde aşağıda uyarlanmış olarak görülen 6 formül kullanılacaktır (Yükçü, 2011: 941):

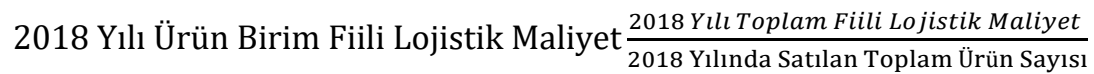

2019 Yılı Toplam Tahmini Lojistik Maliyet $=(2018$ Y1lı Ürün Birim Fiili Lojistik Maliyet* 2019 Yılı Tahmini Ürün Satış Hedefi)

2019 Y1l Toplam Lojistik Maliyet Hedefi $=($ Hedef Lojistik Maliyet $* 2019$ Yı1ı Tahmini Ürün Satı̧̧ Hedefi)

2019 Y1lı Toplam Kaizen Lojistik Maliyet Düşürme Hedefi $=(2019$ Yı1 Toplam Tahmini Lojistik Maliyet - 2019 Y1l Toplam Lojistik Maliyet Hedefi)

Tahsis Oranı: $\frac{\dot{I} \text { lgili Lojistik Faaliyetin Doğrudan Kontrol Ettiğ } i \text { Maliyetler }}{\text { Tüm Lojistik Faaliyetler Tarafından Doğrudan Kontrol Edilen Maliyetler }}$

İlgili Lojistik Faaliyetin Toplam Kaizen Maliyet Hedefi $=(2019$ Y1l Toplam Kaizen Maliyet Hedefi * Lojistik Faaliyetin Tahsis Oran1)

Yukarıda görülen ilk 4 formüle ilişkin hesaplamalardan bazıları hedef maliyet kısmında daha önce hesaplandığı için doğrudan sonuçları yazılmış olup diğerleri ise hesaplanmıştır. Hesaplamalara ilişkin rakamlar için daha önce işletme verilerinin toplu olarak açıklandığı Tablo 1'e bakılabilir. İlk 4 formüldeki sonuçlar ve hesaplamalar aşağıdaki gibidir;

2018 Y1lı Ürün Birim Fiili Lojistik Maliyeti = 44,68 TL

2019 Y1lı Toplam Tahmini Lojistik Maliyet $=44,68 * 94.000=$ 4.199.815,86TL

2019 Y11 Toplam Lojistik Maliyet Hedefi $=42,97 * 94.000=\mathbf{4 . 0 3 9 . 2 6 0 , 7 3}$ TL

2019 Y11ı Toplam Kaizen Lojistik Maliyet Düşürme Hedefi $=4.199 .815,86$ $\mathrm{TL}$ - 4.039.260,73 TL = 160.555,13 TL

Toplam kaizen lojistik maliyet düşürme hedefine ulaşmada bir diğer yol ise işletmenin 2019 yılı ürün birim lojistik maliyet düşürme hedefi (ürün birim fiili lojistik maliyet - ürün birim hedef lojistik maliyet) olan 1,71 TL'nin, işletmenin 2019 yılı hedef satış miktarı olan 94.000 adet ile çarpılmasıdır. Buna göre işletmenin 2019 yılı için hedeflediği lojistik maliyet düşürme tutarı 1,71 $(1,70803) \mathrm{TL}^{*} 94.000=160.555,13$ TL olarak hesaplanmıştır. 
İşletmenin toplam lojistik maliyetlerini, lojistik faaliyetlere dağıtmada kullanılacak olan tahsis oranları her bir faaliyet için ayrı ayrı aşağıdaki gibi hesaplanmıştır:

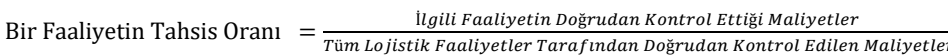

$$
\begin{aligned}
& \text { Sipariş İşleme Tahsis Oranı }=\frac{379.770,58 T L}{3.797 .705,84 T L}=\% \mathbf{1 0} \\
& \text { Ambalajlama Tahsis Oranı }=\frac{949.426,46 T L}{3.797 .705,84 T L}=\mathbf{\%} 25 \\
& \text { Elleçleme Tahsis Oranı }=\frac{113.931,18 T L}{3.797 .705,84 T L}=\% \mathbf{3} \\
& \text { Depolama Tahsis Oranı }=\frac{265.839,41 T L}{3.797 .705,84 T L}=\% 7 \\
& \text { Taşıma Tahsis Oranı }=\frac{2.088 .738,21 T L}{3.797 .705,84 T L}=\% \mathbf{5 5}
\end{aligned}
$$

İşletmenin lojistik faaliyetlerine ilişkin tahsis oranlarının belirlenmesi sonrasında her bir lojistik faaliyete ilişkin tahsis oranı ile düşürülmesi planlanan

\begin{tabular}{|c|c|c|c|}
\hline $\begin{array}{c}\text { Lojistik } \\
\text { Faaliyetler }\end{array}$ & $\begin{array}{l}\text { Tahsis } \\
\text { Oranı } \\
\text { (a) }\end{array}$ & $\begin{array}{c}2019 \text { Yılı Toplam } \\
\text { Kaizen Lojistik Maliyet } \\
\text { Düşürme Hedefi (b) }\end{array}$ & $\begin{array}{c}\text { Her Bir Lojistik Faaliyetin } \\
\text { Kaizen Lojistik Maliyet } \\
\text { Düşürme Hedefi (a*b) }\end{array}$ \\
\hline Sipariş İşleme & $\% 10$ & \multirow{5}{*}{$160.555,13 \mathrm{TL}$} & $16.055,51 \mathrm{TL}$ \\
\hline Ambalajlama & $\% 25$ & & $40.138,78 \mathrm{TL}$ \\
\hline Elleçleme & $\% 3$ & & $4.816,65 \mathrm{TL}$ \\
\hline Depolama & $\% 7$ & & $11.238,86 \mathrm{TL}$ \\
\hline Taşıma & $\% 55$ & & $88.305,32 \mathrm{TL}$ \\
\hline
\end{tabular}
toplam kaizen lojistik maliyet hedefi çarpılır. Bulunan sonuçlar her bir lojistik faaliyete ait kaizen lojistik maliyet hedef tutarıdır. Hesaplama sonucunda bulunan tutarlar aşağıda Tablo 7'de gösterilmiştir.

Tablo 7. Kaizen Lojistik Maliyet Hedeflerinin Hesaplanmas1

\section{İşletme Maliyetlerinin Optimizasyonunda Kısıtlar Teorisinin Kullanılması}

İşletme haftanın 6 günü çalışmakta olup, aylık toplamda 26 gün ve yılda 312 gün çalışmaktadır. Dolayısı ile 2018 yılında işletme 312 gün faaliyet göstermiş olup üretim yapmıştır. İ̧̧letmede günlük çalışma süresi 8 saattir. Buna göre 2018 yılı için işletmede gerçekleştirilen faaliyetlerin her birinin kaç dakika sürdüğü 
tespit edilmiş olup akabinde üretilen ürün sayısı ile çarpılarak bulunan toplam süre verileri aşağıdaki tabloda verilmiştir.

Tablo 8. Lojistik Faaliyetlerin Tamamlanma Sürelerinin Tanımlanması

\begin{tabular}{|l|l|r|r|r|}
\hline $\begin{array}{c}\text { Lojistik } \\
\text { Faaliyetler }\end{array}$ & Ürün & $\begin{array}{c}\text { Birim Başına } \\
\text { Süre (dk) }\end{array}$ & $\begin{array}{c}\text { 2018 Yılında } \\
\text { Üretilen Ürün Sayısı } \\
\text { (Adet) }\end{array}$ & $\begin{array}{c}\text { Toplam Süre } \\
\text { (dk) }\end{array}$ \\
\hline Sipariş İşleme & Tüfek & $1,35 \mathrm{dk}$ & $85.000 \mathrm{adet}$ & $114.750 \mathrm{dk}$ \\
\hline Ambalajlama & Tüfek & $1,90 \mathrm{dk}$ & $85.000 \mathrm{adet}$ & $161.500 \mathrm{dk}$ \\
\hline Elleçleme & Tüfek & $0,90 \mathrm{dk}$ & $85.000 \mathrm{adet}$ & $76.500 \mathrm{dk}$ \\
\hline Depolama & Tüfek & $1,25 \mathrm{dk}$ & $85.000 \mathrm{adet}$ & $106.250 \mathrm{dk}$ \\
\hline Taşıma & Tüfek & $1,50 \mathrm{dk}$ & $85.000 \mathrm{adet}$ & $127.500 \mathrm{dk}$ \\
\hline
\end{tabular}

Aşağıdaki tabloda görülen ürün fiili kapasite sütununda görülen rakamlar yukarıdaki tabloda hesaplanmış olan toplam süre sütununda gelmektedir. İşletmenin teorik kapasitesi ise her lojistik faaliyet alanında işletmenin kaç dakika çalışabildiğini göstermektedir. İşletme yılda 312 gün ve günlük 8 saat çalışacağından ve 1 saat 60 dakika olduğundan işletmenin maksimum çalışma kapasitesi $(312 * 8 * 60)=149.760 \mathrm{dk}$ olarak hesaplanmıştır. Fiili kapasite ile teorik kapasite arasındaki fark olumlu ise işletmenin ilgili lojistik faaliyetinde herhangi bir kısıt olmadığı, farkın olumsuz olması durumunda ise ilgili lojistik faaliyette bir kısıtın söz konusu olduğu görülecektir. Yine benzer şekilde kapasite kullanım oranı fiili kapasitenin teorik kapasiteye bölünmesi ile bulunur. $\mathrm{Bu}$ işlem sonrasında bulunan oran 1'in üzerindeyse kısıt bulunmaz iken, eğer oran 1'in üzerinde ise işletmede kısıt olduğu söylenir.

Tablo 9. İşletmenin Lojistik Faaliyetlerindeki Kısıtların Tanımlanması

\begin{tabular}{|l|r|r|r|c|}
\hline & \multicolumn{1}{|c|}{} & & \\
Faaliyetler & $\begin{array}{c}\text { Ürün Fiili } \\
\text { Kapasite (dk) }\end{array}$ & $\begin{array}{c}\text { Teorik } \\
\text { Kapasite (dk) }\end{array}$ & \multicolumn{1}{c|}{ Fark (dk) } & $\begin{array}{c}\text { Kapasite } \\
\text { Kullanım Oranı }\end{array}$ \\
\hline Sipariş İșleme & $114.750 \mathrm{dk}$ & $149.760 \mathrm{dk}$ & $35.010 \mathrm{dk}$ & 0,77 \\
\hline Ambalajlama & $\mathbf{1 6 1 . 5 0 0 ~ d k}$ & $\mathbf{1 4 9 . 7 6 0 ~ d k}$ & $\mathbf{- 1 1 . 7 4 0 ~ d k}$ & $\mathbf{1 , 0 8}$ \\
\hline Elleçleme & $76.500 \mathrm{dk}$ & $149.760 \mathrm{dk}$ & $73.260 \mathrm{dk}$ & 0,51 \\
\hline Depolama & $106.250 \mathrm{dk}$ & $149.760 \mathrm{dk}$ & $43.510 \mathrm{dk}$ & 0,71 \\
\hline Taşıma & $127.500 \mathrm{dk}$ & $149.760 \mathrm{dk}$ & $22.260 \mathrm{dk}$ & 0,85 \\
\hline
\end{tabular}

Yukarıdaki tablo incelendiğinde işletmenin sipariş işleme, elleçleme, depolama ve taşıma lojistik faaliyetlerinde işletme kapasitesinin altında çalıştı̆̆ 1 görülmektedir. Fakat ambalajlama lojistik faaliyetinde ise kapasite kullanım 
oranı 1,08 olup, işletmenin teorik kapasitenin üzerinde bir kapasite kullandığ ($11.740 \mathrm{dk}$ ) görülmektedir.

İşletmede ambalajlama lojistik faaliyetinde yapılan incelemede ambalajlama bölümünde 2 adet ambalajlama makinası bulunduğu ve 3 çalışanın bu iki makinayı kullandığı tespit edilmiştir. Yapılan piyasa araştırması sonucunda yeni bir ambalajlama makinası satın alınarak ambalajlama faaliyetinde kapasitenin $50.000 \mathrm{dk}$ artırılabileceği hesaplanmıştır.

Tablo 4. Ambalajlama Kısıtının Giderilmesi Sonucunda Kısıtların Tekrar Tanımlanmas 1

\begin{tabular}{|l|r|r|r|r|r|}
\hline \multicolumn{1}{|c|}{ Faaliyetler } & $\begin{array}{c}\text { Ürün Fiili } \\
\text { Kapasite (dk) }\end{array}$ & $\begin{array}{c}\text { Teorik } \\
\text { Kapasite (dk) }\end{array}$ & Fark (dk) & $\begin{array}{c}\text { Kapasite } \\
\text { Kullanım } \\
\text { Oranı }\end{array}$ & $\begin{array}{c}\mathbf{2 0 1 9} \text { Yılı } \\
\text { Tahmini } \\
\text { Kapasite(dk) }\end{array}$ \\
\hline Sipariş İşleme & $114.750 \mathrm{dk}$ & $149.760 \mathrm{dk}$ & $35.010 \mathrm{dk}$ & 0,77 & $126.900 \mathrm{dk}$ \\
\hline Ambalajlama & $\mathbf{1 6 1 . 5 0 0 ~ d k}$ & $\mathbf{1 9 9 . 7 6 0 ~ d k}$ & $\mathbf{3 8 . 2 6 0 ~ d k}$ & $\mathbf{0 , 8 1}$ & $\mathbf{1 7 8 . 6 0 0 ~ d k}$ \\
\hline Elleçleme & $76.500 \mathrm{dk}$ & $149.760 \mathrm{dk}$ & $73.260 \mathrm{dk}$ & 0,51 & $84.600 \mathrm{dk}$ \\
\hline Depolama & $106.250 \mathrm{dk}$ & $149.760 \mathrm{dk}$ & $43.510 \mathrm{dk}$ & 0,71 & $117.500 \mathrm{dk}$ \\
\hline Taşıma & $127.500 \mathrm{dk}$ & $149.760 \mathrm{dk}$ & $22.260 \mathrm{dk}$ & 0,85 & $141.000 \mathrm{dk}$ \\
\hline
\end{tabular}

$\mathrm{Bu}$ yeni makinenin alınması durumunda ortaya çıkacak yeni teorik kapasite ise yukarıdaki tabloda gösterilmiştir. Ayrıca tabloda en sağdaki sütunda, faaliyetlerin birim başına süresi değişmezse 94.000 adet ürün üretme hedefi dikkate alınarak 2019 yılı tahmini kapasiteleri gösterilmiştir. Teorik kapasite 149.760 dk'yı hiçbir zaman aşamayacak olup burada kısıtın giderildiğini vurgulamak için teorik kapasiteye $50.000 \mathrm{dk}$ eklenerek $199.760 \mathrm{dk}$ olarak yazılmıştır. Ambalajlama makinaları alındığında ambalajlama süresi tekrar hesaplanacak ve bu sürenin teorik kapasitenin altında kaldığ görülecektir.

\section{SONUÇ}

Lojistik gibi dünya ekonomisinde önemli bir yer tutan, rekabetin amans1z olduğu, birçok sektörü ve operasyonu birbirine bağlayan bir alanda, doğru ve detaylı maliyet bilgisine olan ihtiyaç teknolojik değişime paralel olarak sürekli artış göstermektedir. Küreselleşme ve bilgi teknolojilerindeki dönüşüm sonucunda tüm sektörlerde olduğu gibi lojistik sektöründe de müşteriler daha uygun bir maliyet ile tam zamanında, şeffaf ve güvenilir bir hizmet talep etmektedirler. Lojistik; depolama, stok yönetimi, gümrükleme, sigortalama, taşıma, elleçleme gibi karmaşıklık düzeyi yüksek başlıklar altında bulunan faaliyetlerden oluşmaktadır. $\mathrm{Bu}$ lojistik faaliyetlerin etkin bir şekilde yürütülmesi, işletmeye maliyetinin doğru bir şekilde hesaplanması ve maliyet düşürmenin etkin bir şekilde sağlanması işletme için büyük önem arz etmektedir. 
Bugün, işletmelerin piyasada belirlenen fiyatı değiştirebilmeleri yoğun rekabet nedeniyle neredeyse imkansızdır. Aynı zamanda ortakların da kar düzeyini koruma eğilimleri söz konusudur. Bu noktadan hareketle, fiyat= maliyet $+k a r$ denkleminde işletmelerin sadece maliyetleri minimize edebilmek için çaba harcayabilecekleri söylenebilir. Lojistikte gelişen teknolojinin ve çağdaş maliyet yöntemlerinin kullanılması ile maliyetlerin optimize edilmesi mümkün olmaktadır. $\mathrm{Bu}$ noktada lojistik maliyetlerin hesaplanması ve optimize edilmesinde çağdaş maliyet yöntemlerinin birlikte kullanılması büyük önem arz etmektedir.

Lojistik maliyetler konusunda çağdaş maliyet yöntemlerinin entegre olarak kullanıldığ 1 çalışma Türkçe literatürde bulunmamaktadır. Yapılan araştırma ile çağdaş maliyet yöntemlerinden hedef maliyetleme, değer analizi, kaizen maliyetleme ve kısıtlar teorisinin entegrasyonu sonucunda aşağıdaki temel bulgulara ulaşılmıştır:

- Lojistik maliyetler, hedef maliyet yöntemi ve değer analizi entegrasyonu ile maliyet eksiği ve fazla maliyete katlanma noktasında analiz edilmiştir. $\mathrm{Bu}$ hesaplamaya göre sipariş işlemede gümrükleme ve personel; ambalajlamada ambalaj malzemesi; elleçlemede forklift-crane masrafları ile elleçlemede kullanılan malzeme; depolamada forklift-crane masrafları; taşımada ise yakıt alt parçalarının maliyet endeksi 1'den küçüktür. Buna göre bu parçalarda işletme fazla maliyete katlandığından, bu parçalarda maliyetlerin azaltılması gerekmektedir. Ancak sipariş işlemede müşteri hizmetleri; ambalajlamada personel ve sarf malzemesi, elleçlemede personel; depolamada personel, kiralama antrepo konteyner, diğer (aydınlatma, 1sıtma, güvenlik vb.); taşımada ise personel, sigorta ve yol masrafları alt parçalarının maliyet endeksi 1'den büyüktür. Diğer bir deyişle, bu parçalarda maliyetler sabit tutularak fonksiyonelliğin arttırılması gerekmektedir.

- Hedef maliyetleme ve değer analizi ile lojistik maliyetlerin ne kadarlık kısmının optimize edilebileceği tespit edilememektedir. Bu nedenle kaizen maliyetleme yöntemindeki tahsis oranları kullanılarak hedef maliyet yöntemiyle belirlenen iyileştirilme ihtiyacı olan maliyet kalemlerinin tutarları belirlenmiş ve her kalemde ne kadar iyileştirilme yapılması gerektiği saptanmıştır. Buna göre işletmenin 2019 yılı için hedeflediği lojistik maliyet düşürme tutarı 1,71 $(1,70803) \mathrm{TL} * 94.000=160.555,13 \mathrm{TL}$ olarak hesaplanmış ve tahsis oranları kullanılarak sipariş işleme faaliyetinde $16.055,51 \mathrm{TL}$, ambalajlama faaliyetinde 40.138,78 TL, elleçleme faaliyetinde 4.816,65 TL, depolama faaliyetinde $11.238,86 \mathrm{TL}$ ve taşıma faaliyetinde $88.305,32 \mathrm{TL}$ maliyet indirimine gidilmesi gerektiği tespit edilmiştir. Her faaliyet alanında hedef maliyet endeksi 1'den küçük olan parçalar öncelikli olarak incelenip bunlarda değer katmayan faaliyetler ortadan kaldırılarak, tedarikçi değiştirerek ya da pazarlık yaparak maliyet düşürme hedefleri yakalanmaya çalışılmalıdır. Buna ek olarak hedef 
maliyet endeksi 1'den büyük olan parçalarda da mümkünse fonksiyonellik artırarak hedeflere ulaşılmaya çalışılmalıdır. Örneğin işletme sipariş işleme fonksiyonunun gümrük işlemleri ve personel parçalarında kaizen maliyetleme ile bulunan tutar kadar maliyet düşürmeye çalışmalıdır. Sarf malzemesinde ise endeks değerinde bir değişiklik yapmaya gerek olmamakta iken müşteri hizmetlerinde de maliyet düşürme yerine fonksiyonelliğin artırılması için çaba gösterilmelidir. Ambalajlama malzemesi alt parçasının maliyet ağırlığı olarak da \%87 gibi yüksek bir orana sahip olması nedeniyle özellikle tedarikçiler ile yapılacak pazarlıklar, farklı ambalajlama malzemelerinin incelenmesi, piyasa araştırmasının yeniden yapılması gibi farklı yöntemler bu noktada kullanılarak kaizen maliyet düşürme hedefi tutarına ulaşılmaya çalışılmalıdır. Elleçleme parçasında ise forklift-crane masraflarının maliyet ağrılığının \%76 olması nedeniyle yüklerin bir araya getirilerek elleçlenmesi, forkliftlerin çalışma sürelerinin azaltılması gibi konularda süreçlerin izlenmesi ve takibi önemlidir. Benzer şekilde depolama parçasında da forklift-crane masraflarının azaltılması gerekmektedir. Taşıma parçasında ise hedef tutara ulaşabilmek için özellikle yakıt giderlerinin indirilmesi gerekmektedir. Rotalama, tarihleri birbirine yakın olan sevkiyatlarda müşteriler ile anlaşma sağlanarak birleştirme, benzin istasyonları ile fiyat indirimi konusunda pazarlık yapma gibi farklı çözüm yolu aranmalidır.

- Ayrıca Kısıtlar Teorisi yöntemi ile işletmenin lojistik faaliyet ve alt faaliyet parçalarında kısıtlar tespit edilmiş ve düzeltildiğinde mevcut durumun ne olacă̆ 1 ortaya konmuştur. İşletmenin teorik kapasitesi $149.760 \mathrm{dk}$ olup, 2018 y1lında 85.000 adet ürün üretimi yapması sonucunda ambalajlama faaliyetinin fiili kapasitesinin $161.500 \mathrm{dk}$ olarak gerçekleştiği tespit edilmiştir. Ambalajlama lojistik faaliyetinde kapasite kullanım oranı 1,08 olup, işletmenin teorik kapasitenin üzerinde bir kapasite kullandığ 1 (-11.740 dk) görülmüştür. İşletme yöneticileri ile yapılan görüşmede bu durum doğrulanmış, ambalajlama aşamasında yaşadıkları zorluklar nedeniyle diğer departmanlarda çalışan elemanlardan yardım alındığ el ile ambalajlama yapıldığı ama kalitede bir takım sıkıntıların olduğu belirtilmiştir. İşletmede ambalajlama lojistik faaliyetinde yapılan incelemede ambalajlama bölümünde 2 adet ambalajlama makinası bulunduğu ve 3 çalışanın bu iki makinayı kullandığı tespit edilmiştir. Yapılan piyasa araştırması sonucunda yeni bir ambalajlama makinası satın alınarak ambalajlama faaliyetinde kapasitenin $50.000 \mathrm{dk}$ artırılabileceği hesaplanmış ve böylece ilgili kısıt ortadan kaldırılmıştır.

- Tüm bunların sonucunda işletmenin optimal maliyet yapısı sağlanmıştır.

Yukarıdaki açıklamalar bir bütün olarak değerlendirildiğinde bu maliyet entegrasyonu ile çok boyutlu olarak maliyetlerin hesaplanabilmesi yöneticilerin karar alma aşamasında daha objektif ve doğru karar almalarına yardımcı olacaktır. Bunun yanı sıra maliyetlerin faaliyetlere göre daha ayrıntılı olarak belirlenebilmesi de işletme operasyonlarında maliyet kontrolünün sağlanması 
açısından kolaylıklar sağlayacaktır. Çalışma bu boyutunun ötesinde akademisyenler tarafından farklı maliyet yöntemleri kullanılarak genişletilebilirse muhasebe ve lojistik bilim alanlarına faydalı olacă̆ 1 düşünülmektedir. Ayrıca bu çalışma, lojistik sektöründeki yönetici ve muhasebe uygulamacıları tarafindan sektöre uyarlandığında sektörel veri işleme ve karar alma boyutunda yararlı olacaktır. Diğer bir deyişle, sektörde çağdaş maliyet yöntemlerini uygulamak isteyen uygulamacılara bu tür çalışmaların nasıl yapılacağ konusunda kaynak sağlanmış olacaktır. Fakat bu yöntemlerin bir arada kullanılması hususunda, uygulama adımlarını doğru bir şekilde yürütecek olan kalifiye elemanları seçmeleri için işletmelerin insan kaynakları politikalarını güncellemeleri ve bu elemanların yetiştirilmeleri noktasında sektör ve akademik dünya arasında yoğun bir işbirliği önerilmektedir.

\section{KAYNAKÇA}

Altınbay, A. (2006). Kaizen maliyetleme sistemi: dinamik bir maliyet yönetimi sistemi. Afyon Kocatepe Üniversitesi IIIBF Dergisi, 8(1), 103-121.

Aslan, S. ve Karavaizoğlu, S. N. (2009). Maliyet tabanlı lojistik yönetimi. Marmara Üniversitesi Sosyal Bilimler Enstitüsü Öneri Dergisi, 8(32), 61-71.

Bilginoğlu, F. (1995). Hedef maliyetleme: yeni bir yönetim aracı. Yönetim Dergisi, 6(21), 13-15.

Bozdemir, E. (2010). Rekabet Üstünlüğü Açısından Hedef ve Kaizen Maliyetleme Yöntemlerinin Türk Otomotiv Sektöründe Uygulanabilirlik Düzeyinin Incelenmesi. [Yayımlanmamış Doktora Tezi], Atatürk Üniversitesi.

Büyükyılmaz, O. ve Gürkan, S. (2009). Süreçlerde en zayıf halkanın bulunması: kısitlar teorisi. ZKÜ Sosyal Bilimler Dergisi, 5 (9), 177-195.

Christopher, M. (2011). Logistics \& supply chain management. Pearson. United Kingdom.

Cooper, R. and Slagmulder, R. (1997). Target costing and value engineering. Productivity Press, Portland, Oregon, USA.

Doğan, S. ve Kılıç, S. (2008). İlişki yönetiminde iç ve dış müşteri memnuniyetinin sağlanması. Karamanoğlu Mehmetbey Üniversitesi Sosyal ve Ekonomik Araştırmalar Dergisi, 2008(1), 60-87.

Donath, B., M., Joe, Dubin, C. and Patterson, P. (2002). The IOMA handbook of logistics and inventory management. John Wiley \& Sons, New York. 
Ellram, L. M. (2006). The implementation of target costing in the United States: theory versus practice. Journal of Supply Chain Management, 42(1), 1326.

Engblom, J., S., Tomi, Töyli, J. and Ojala, L. (2012). Multiple-method analysis of logistics costs. International Journal of Production Economics, 137(1), 29-35.

Ergül, A. (2014). Hedef maliyetleme çerçevesinde çağdaş maliyet yöntemlerinin maliyet etkinliği boyutunda entegrasyonu ve konaklama işletmelerinde uygulanması. [Yayımlanmamış Doktora Tezi], Akdeniz Üniversitesi.

Geri, N. and Ahituv, N. (2008). A theory of constraints approach to interorganizational systems implementation. Information Systems and EBusiness Management, 6(4), 341-360.

Gürdal, K. (2007). Maliyet yönetiminde güncel yaklaşımlar. Siyasal Kitabevi. Ankara.

Hacırüstemoğlu, R. ve Şakrak, M. (2002). Maliyet muhasebesinde güncel yaklaşımlar. Türkmen Kitapevi. İstanbul.

Huang, L. (1999). The integration of activity-based costing and the theory of constraints. Journal of Cost Management, (November-December), 2127, http://maaw.info/ArticleSummaries/ArtSumHuang99.htm, (Erişim Tarihi: 09.09.2019).

Imai, M. (1986). KAIZEN, The key to Japan's competitive success, McCraw-Hill Publishing Company.

İlhan, E. (2014). Kisıtlar teorisi ve bir üretim işletmesinde uygulama, [Yayımlanmamış Yüksek Lisans Tezi], Uludağ Üniversitesi.

Kaygusuz, S. Y. (2005). Kısıtlar teorisi: varsayımlar, süreç ve bir uygulama, Ankara Üniversitesi SBF Dergisi, 60(4), 133-156.

Marzouk, M. M. (2011). ELECTRE III model for value engineering applications. Automation in Construction, 20(5), 596-600.

Modarress, B., Ansari, A.and Lockwood, D.L. (2005). Kaizen costing for lean manufacturing: a case study. International Journal of Production Research, 43(9), 1751-1760.

Nave, D. (2002). How to compare six sigma, lean and the theory of constraints, Process Improvement, March, 73-78. 
Örnek, A. Ş. (2003). Bir yönetim tekniği olarak değer mühendisliği. Dokuz Eylül Üniversitesi Sosyal Bilim Enstitüsü Dergisi, (5)2, 213-230.

Özdemir, F. S. (2007). Lojistik maliyet yönetiminde optimizasyonla sağlanan etkinlik artışının işletmelerin finansal yapısı üzerindeki etkisinin taşıma maliyetleri yönünden incelenmesi. [Yayımlanmamış Yüksek Lisans Tezi], Gazi Üniversitesi.

Pekmezci, T. Demireli, C. ve Batman, G. (2008). İç müşteri memnuniyeti: Konya un fabrikalarında bir uygulama. Dumlupınar Üniversitesi Sosyal Bilimler Dergisi, (22). 143-156.

Quillian, L. (1991). Curing 'Functional Silo Syndrome' with logistics TCM. CMA Magazine, 65(5), 9-13.

Rantasila, K. and Ojala, L. (2012). Measurement of national-level logistics costs and performance. International Transport Forum Discussion Paper. 2-4 May 2012, Leipzig, Germany.

Robeson, J. F. and Copacino, W. C. (2000). The logistics handbook, Free Press.

Ronen, B. (2005). Special issue on the theory of constraints - practice and research, Human Systems Management, (24), 1-2.

Sevim, Ş. ve Elmacı, O. (2007). Sürdürülebilir rekabet üstünlüğü sağlamada kaynak tabanlı yaklaşım modeli ile başarı stratejisinin belirlenmesinde lojistik süreç maliyetlerinin analizi. Journal of Azerbaijani Studies, 96104.

Taşkın, E. ve Durmaz, Y. (2012). Lojistik faaliyetler hizmet kalitesi ve müşteri değeri. Detay Yayınc1lı.

Tiryakigil, S. (2011). Malzeme yönetiminde kısitlar teorisi ile maliyet azaltımı ve bir uygulama, [Yayımlanmamış Yüksek Lisans Tezi] Dokuz Eylül Üniversitesi.

Tokay, S. H., Deran, A. ve Arslan, S. (2011). Lojistik maliyet yönetiminde izlenebilecek stratejiler ve muhasebe eğitiminden beklentiler. Dumlupınar Üniversitesi Sosyal Bilimler Dergisi, 29, 225244.

Ünal, E. N., Demircioğlu, M. ve Küçüksavaş, N. (2006). Optimal ürün karmas1 belirlemede faaliyete dayalı maliyet sistemi ve kısitlar teorisi. Çukurova Üniversitesi Sosyal Bilimler Enstitüsü Dergisi, 15(2), 327-343. 
Yurtay, Y. Yurtay, N. Akçetin, E. ve Kılıç, A. (2014). Konteynerde yük optimizasyonu: örnek uygulama. Yönetim ve Ekonomi Araştırmaları Dergisi, 12(23), 228-247.

Yükçü, S. (2011). Yönetim açısından maliyet muhasebesi. Altın Nokta Yayınevi.

Weiyi, F. and Luming, Y. (8-9 August 2009). The discussion of target cost method in logistics cost management, ISECS International Colloquium on Computing, Communication, Control, and Management, 537-540. 